\title{
FACIES HETEROGENEITY OF A DEEP-SEA DEPOSITIONAL LOBE COMPLEX: CASE STUDY FROM THE SLONNE SECTION OF SKOLE NAPPE, POLISH OUTER CARPATHIANS
}

\author{
Piotr LAPCIK \\ Institute of Geological Sciences, Jagiellonian University, ul. Gronostajowa 3a, 30-063 Kraków, Poland; \\ e-mail: piotr.lapcik@doctoral.uj.edu.pl
}

Łapcik, P., 2017. Facies heterogeneity of a deep-sea depositional lobe complex: case study from the Słonne section of Skole Nappe, Polish Outer Carpathians. Annales Societatis Geologorum Poloniae, 87: 301-324.

\begin{abstract}
This article reports on the first detailed study of the Skole Nappe's Ropianka Formation in the Słonne outcrop section along river San. Lithological and micropalaeontological similarities indicate that the sedimentary succession correlates with the formation's Wiar Member of Campanian-late Maastrichtian age. The sedimentary succession, more than $140 \mathrm{~m}$ thick, is interpreted as a deep-marine complex of turbiditic depositional lobes and the study reveals its sedimentary anatomy. Six component facies of sediment gravity-flow deposits and their stratigraphic grouping into four facies associations are recognized, with these latter considered to represent deposits of the lobe axial zone, lateral flank zone and featheredge fringe zone, as well as an interlobe outer-fringe zone. Semi-quantitative characterization and comparison of facies associations gives insight into the succession's sedimentary heterogeneity. Six depositional lobes superimposed upon one another are recognized in the stratigraphic succession, and their pattern of vertical stacking is interpreted in terms of dynamic stratigraphy on the basis of the upward succession of facies associations. The stratigraphic arrangement of facies associations is attributed to autogenic morphodynamic changes within the evolving depositional system, although it cannot be precluded that also eustatic and local tectonic forcing came into play. The case study sheds more light on the sedimentary environment, sediment sourcing system and spatial depositional pattern in the Late Cretaceous Skole Basin, where the aggrading seafloor apparently oscillated around the lysocline depth that could be mid-bathyal at that time.
\end{abstract}

Key words: Deep-marine turbidites, depositional lobes, dynamic stratigraphy, facies analysis, mass-flow deposits, Upper Cretaceous.

Manuscript received 9 May 2017, accepted 20 December 2017

\section{INTRODUCTION}

Modern methodology for the analysis of deep-water turbiditic systems relies on the recognition of architectural elements (Pickering et al., 1995; Clark and Pickering, 1996; Stow and Mayall, 2000; Johnson et al., 2001; Posamentier and Kolla, 2003; McHargue et al., 2011), alluding to the methodology postulated originally for fluvial systems (Miall, 1985, 1989). One of the common architectural elements are packages of thick-bedded sandy turbiditic facies, reported from deep-sea fan feeder canyons/valleys, channel-fills, lateral or terminal splays and depositional lobes (Normark, 1970, 1978; Mutti and Ricci Lucchi, 1975; Walker, 1978; Mutti, 1979, 1985; Pickering et al., 1986, 1989, 1995; Shanmugam and Moiola, 1991; Mulder, 2011). Such packages may then occur in various parts of a sand-prone submarine system and their diagnostic significance depends strongly upon the scale of exposure and lateral facies context.

Thick-bedded successions of mainly massive sandstone turbidites are common in the Polish Carpathian Flysch
(Dżułyński et al., 1959; Unrug, 1963; Leszczyński, 1981; Ślączka. and Thompson, 1981; Warchoł, 2007 and references therein), but the poor exposure with widely isolated outcrops has hindered their interpretation as specific parts of a depositional system. In regional studies, the thicker and laterally most extensive packages with little or no evidence of flow channelization are generally considered to represent depositional lobes.

One of such lithostratigraphic units in the Polish Outer Carpathians is the Ropianka Formation (Turonian-Paleocene) of the Skole Nappe (Fig. 1A). The present field study is from the Słonne section, a 143-m long outcrop of the Ropianka Formation in the eastern bank of river San (Fig. 1B), interpreted herein as representing a stratigraphic complex of laterally shifting depositional lobes. The study has two aims: (1) to distinguish and characterize differing assemblages of turbiditic facies and assign them interpretively to specific zones of depositional lobe (i.e., the axial, 


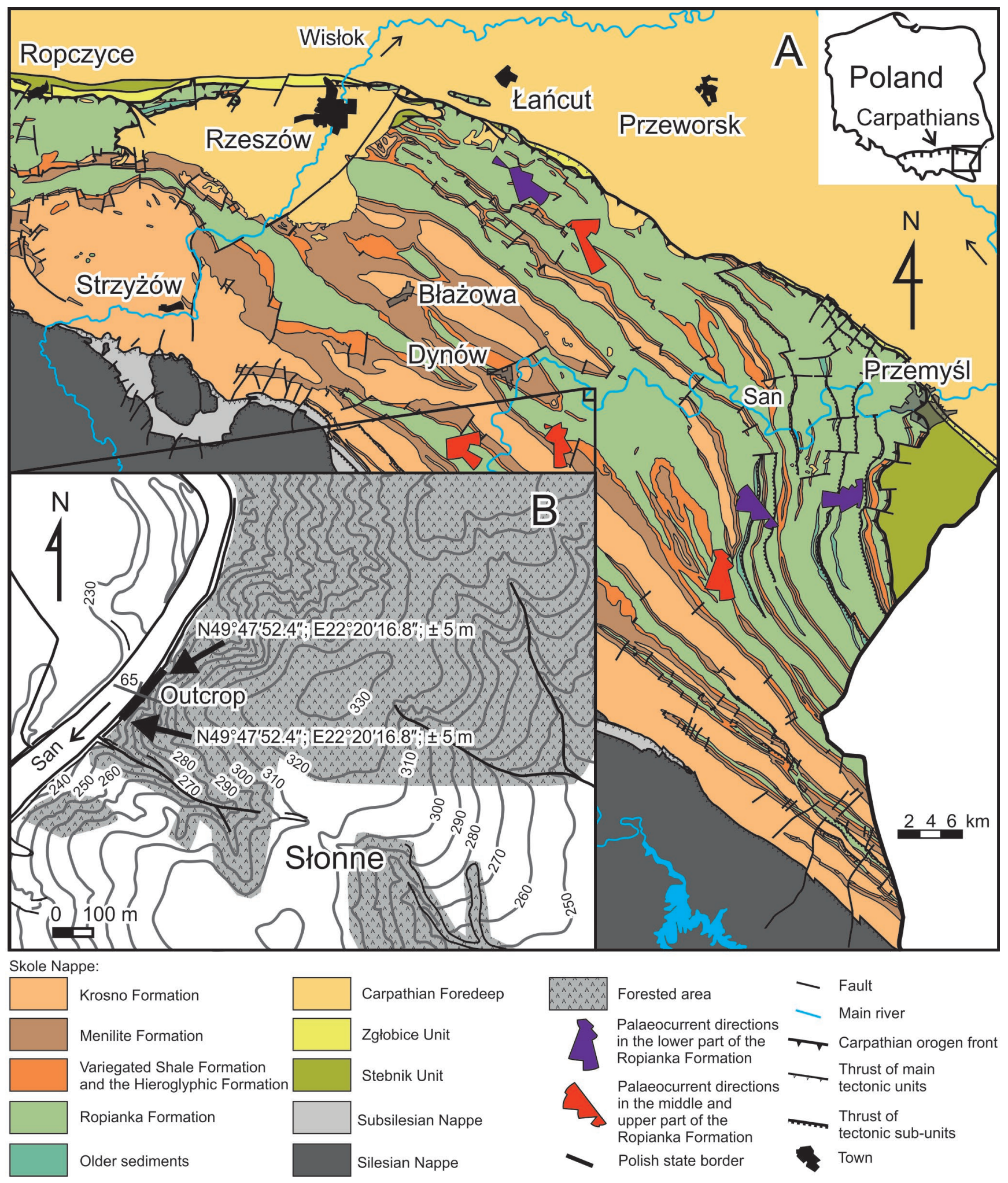

Fig. 1. Location of the study area. A. Geological map of the Skole Nappe; compiled from Gucik et al. (1980), Jurkiewicz and Woiński (1981), Woiński (1994) and Niescieruk et al. (1995), with palaeocurrent directions after Bromowicz (1974). B. Location of the Słonne outcrop section at the bank of river San.

flank, fringe and interlobe zones); and (2) to analyse further the vertical changes of facies assemblages in the stratigraphic section as a hypothetical record of the lateral shifting of depositional lobes. This case study contributes to the general knowledge on the facies heterogeneity of turbiditic depositional lobes and their complexes. 


\section{THE ROPIANKA FORMATION}

The Skole (or Skyba) Nappe is the northernmost major tectono-stratigraphic unit of the Polish Outer Carpathians, known also as the Polish Flysch Carpathians. The term "flysch", as defined by Dżułyński and Smith (1964), denotes a group of deep-marine facies dominated by deposits of sediment gravity flows. The flysch of the Skole Nappe represents a deep-water basin that formed in the Early Cretaceous as the northern branch of the Tethys and existed until the Miocene (Fig. 1), when the northward movement of the Apulian Plate closed the remnant Outer Carpathian basin (Golonka et al., 2006). The Skole Nappe, thrust northwards over the Carpathian Foredeep, was internally folded and cut by internal thrusts (Książkiewicz, 1972; Kotlarczyk, 1978, 1988).

In the Turonian, tectonic activity in the Skole Basin and its hinterland initiated deposition of the flysch of the Ropianka Formation upon an extensive unit of late Cenomanian radiolarian shales (Fig. 2; Kotlarczyk, 1978, 1988; Malata and Poprawa, 2006). The sedimentation of the Ropianka Formation, known also as the Inoceramian Beds, proceeded until the early Palaeogene (Fig. 2). The sedimentation history of the Ropianka Formation comprised three phases, each starting with the deposition of calcareous flysch facies and ending with the deposition of siliciclastic flysch facies (Kotlarczyk, 1978, 1988).

The Ropianka Formation is up to $1.6 \mathrm{~km}$ thick and shows a marked facies change across the basin. With respect to the orogen interior, some authors have distinguished an "internal zone" dominated by sandstones with sparse marlstone intercalations, and an "external zone" with widespread marlstones and with evidence of slumping and debris flows (e.g., Burzewski, 1966; Kotlarczyk, 1978). The present study is from the internal zone. The sediment was generally derived from the NW, N and NE (see palaeocurrents in Fig. 1A; Książkiewicz, 1962; Bromowicz, 1974; Kotlarczyk, 1978, 1988), and the compositional diversity of source terrane is reflected in the wide range of exotic debris in the turbidites, debrites and slump deposits (Kropaczek, 1917; Bukowy, 1957a, b; Bukowy and Geroch, 1957; Kotlarczyk and Śliwowa, 1963; Nowak, 1963; Bromowicz, 1974; Dżułyński et al., 1979; Skulich, 1986; Malata, 2001; Łapcik et al., 2016) as well as in the variation of detrital heavy-mineral suites (Salata and Uchman, 2013; Salata, 2014).

\section{THE SLONNE SECTION}

The Słonne outcrop section studied is in the right-hand bank of river San, about $7 \mathrm{~km}$ to the east of the town of Dynów (Fig. 1). The river-escarpment outcrop is more than $150 \mathrm{~m}$ long and up to $12 \mathrm{~m}$ high, showing flysch beds tectonically tilted to the NNE (general dip $020 / 65^{\circ}$ ). The outcrop section exposes the northern limb of the Słonne Anticline (Rajchel, 1989). Since the Skole Nappe is strongly folded and disrupted by internal thrusts (Wdowiarz, 1939; Jednorowska, 1957; Rajchel, 1989), spatial stratigraphic correlations are a formidable task. Biostratigraphic dating is sparse and its age-resolution insufficient. Local

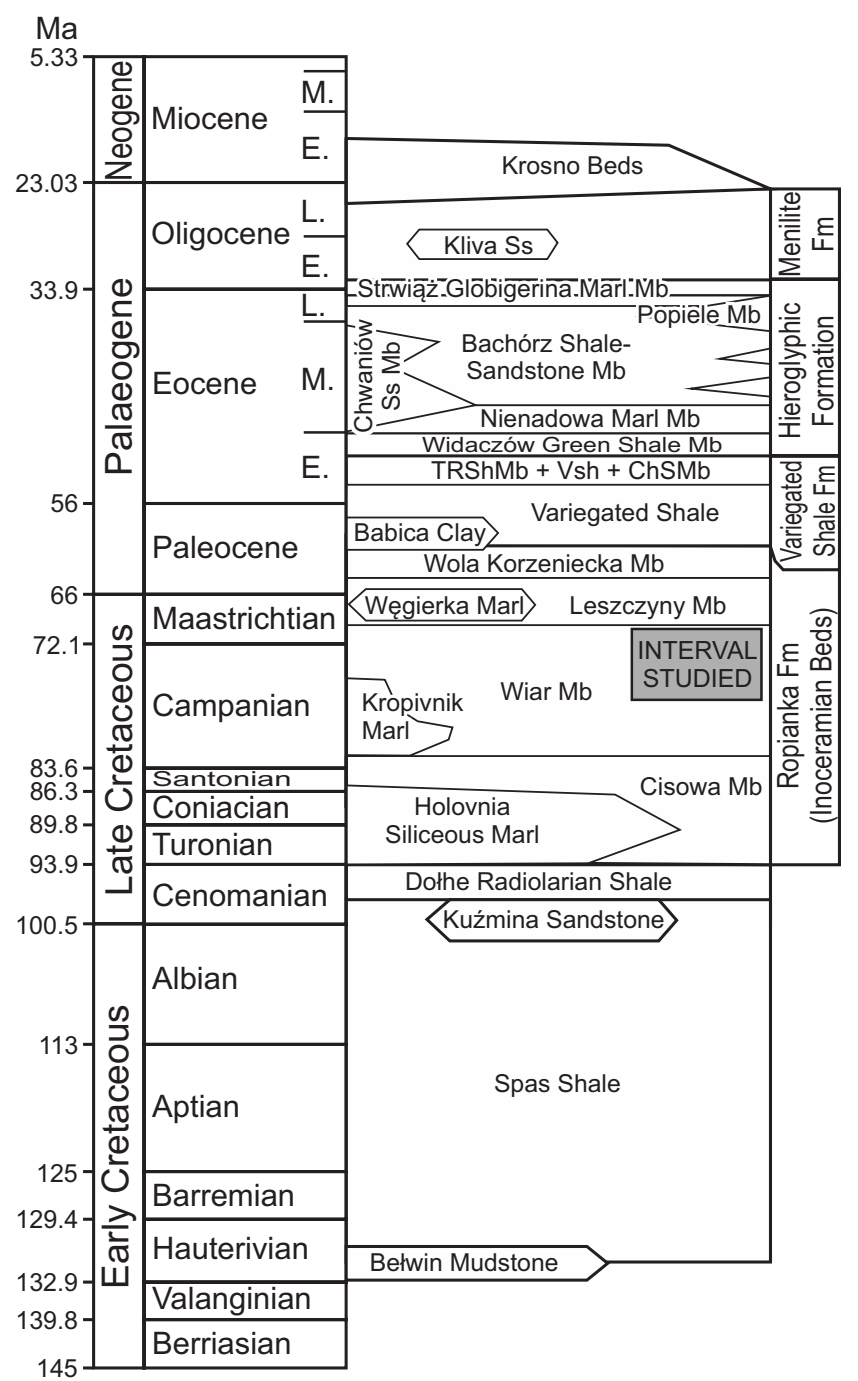

Fig. 2. Stratigraphy of the Skole Nappe, based on Kotlarczyk (1988), Rajchel (1990), Rajchel and Uchman (1998) and Ślączka and Kaminski (1998), with modifications by Gedl (1999) and Kotlarczyk et al. (2006). The time scale is according to Gradstein et al. (2012). Abbreviations: TRSh Mb - Trójca Red Shale Member; VSh - Variegated Shale; and ChS Mb - Chmielnik Stripy Sandstone Member.

drilling cores (see boreholes Słonne 1, 4 and 9-12 in Jednorowska, 1957) and surface mapping (Rajchel, 1989) in the close surroundings of the study area suggest that the investigated stratigraphic section corresponds to the Wiar Member (Campanian-early Maastrichtian) and possibly the lower part of the overlying Leszczyny Member (late Maastrichtian-earliest Paleocene) of the Ropianka Formation (Fig. 2). Lithological similarity to Rajchel's (1989) stratigraphic "Complex I" favours correspondence to the middle to upper Wiar Member (Fig. 2).

The outcrop section shows alternating intervals, from a couple of metres to more than $10 \mathrm{~m}$ thick, that range from thick-bedded amalgamated sandstones to thin-bedded heterolithic deposits with mudstone and marlstone interlayers (Fig. 3). Local gaps in the outcrop are due to the riverbank collapse, modern fluvial cover or low relief, which suggests mainly mud-rich intervals of the section (Fig. 3). 


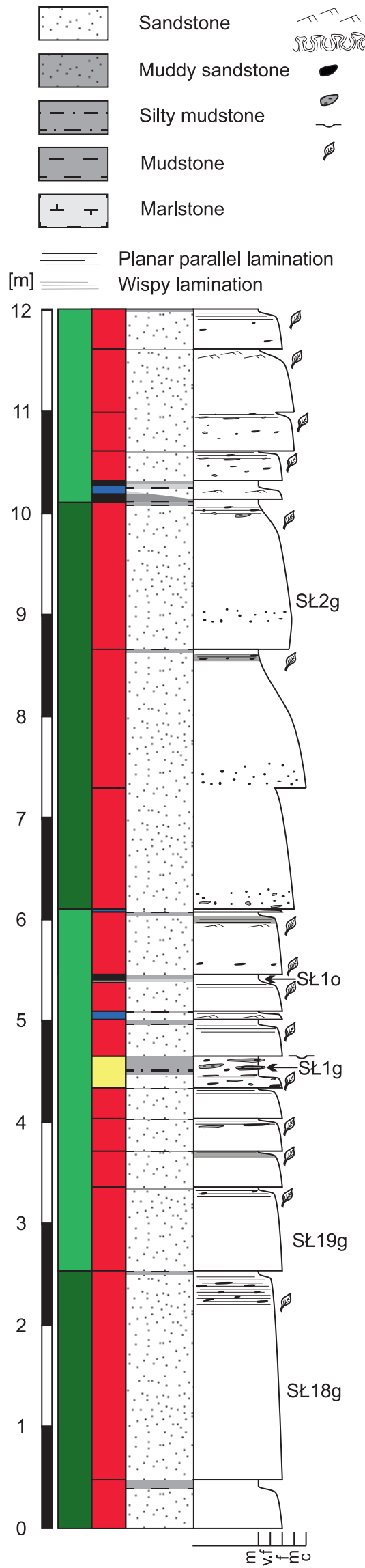

Ripple cross-lamination

Convolute lamination

Coal clast

Mudstone clast

Sole marks

Enrichment in plant detritus
Sedimentary facies:

Facies F1

Facies F2

Facies F3/F4

Facies F5

Facies F6

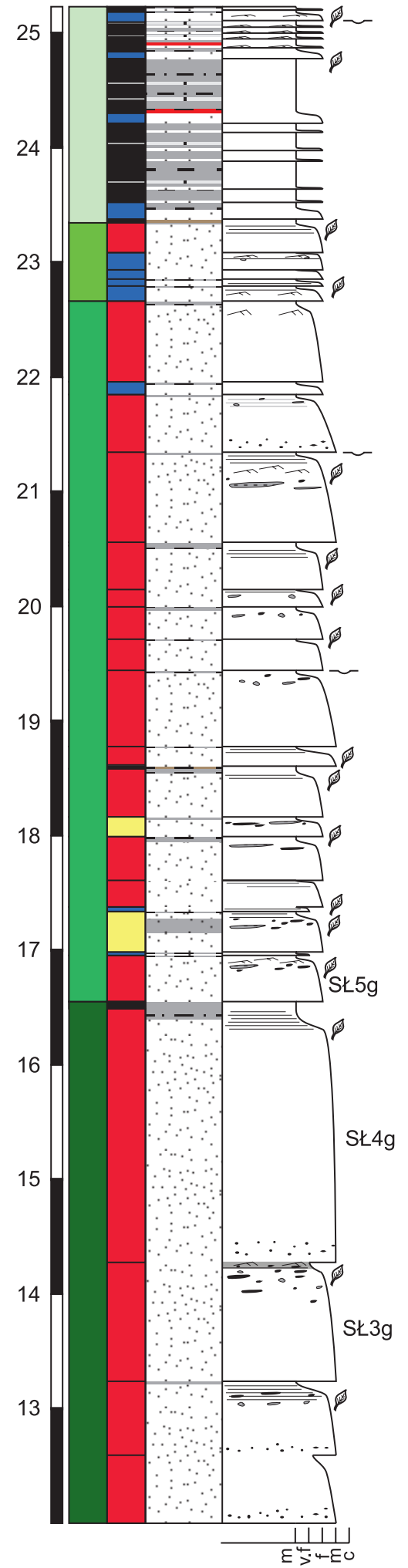

Facies associations:

$\square$ Lobe-axis deposits

$\square$ Lobe-flank deposits

$\square$ Lobe-fringe deposits

Interlobe/distal fringe deposits
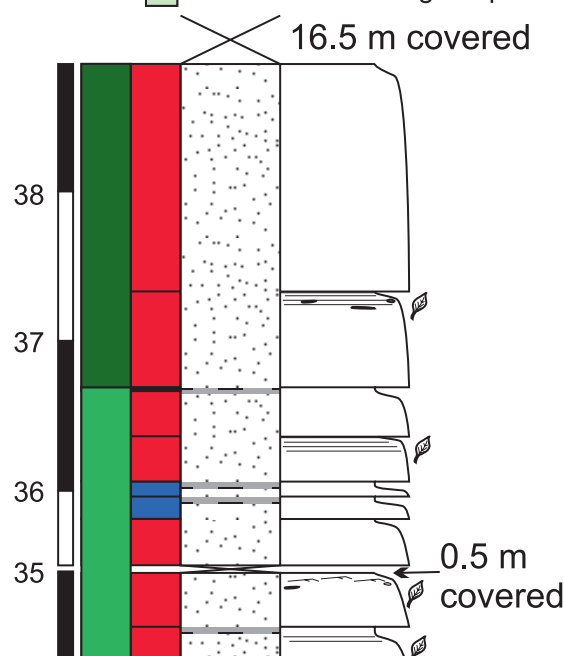

34

32

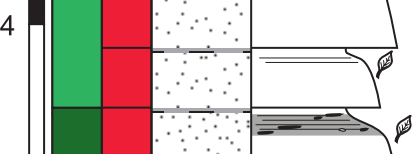

33

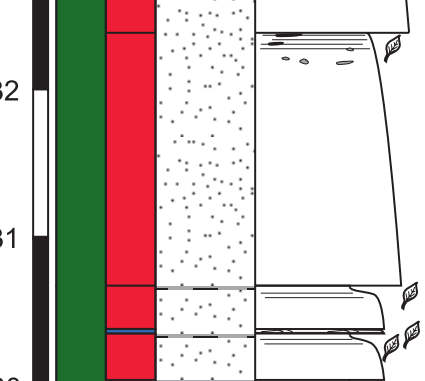

30

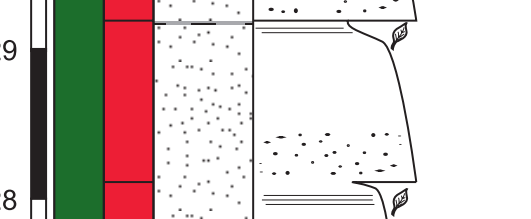

28

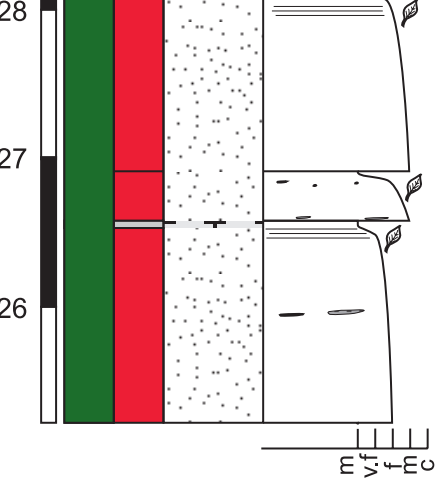

Fig. 3. Detailed sedimentological log of the Ropianka Formation in the Słonne outcrop section, with the distinction of sedimentary facies and their associations (see legend). Symbols SŁo along the log indicate samples taken for micropalaeontological analysis and symbols SŁg indicate samples taken for grain-size analysis. Continuation in the next pages. 

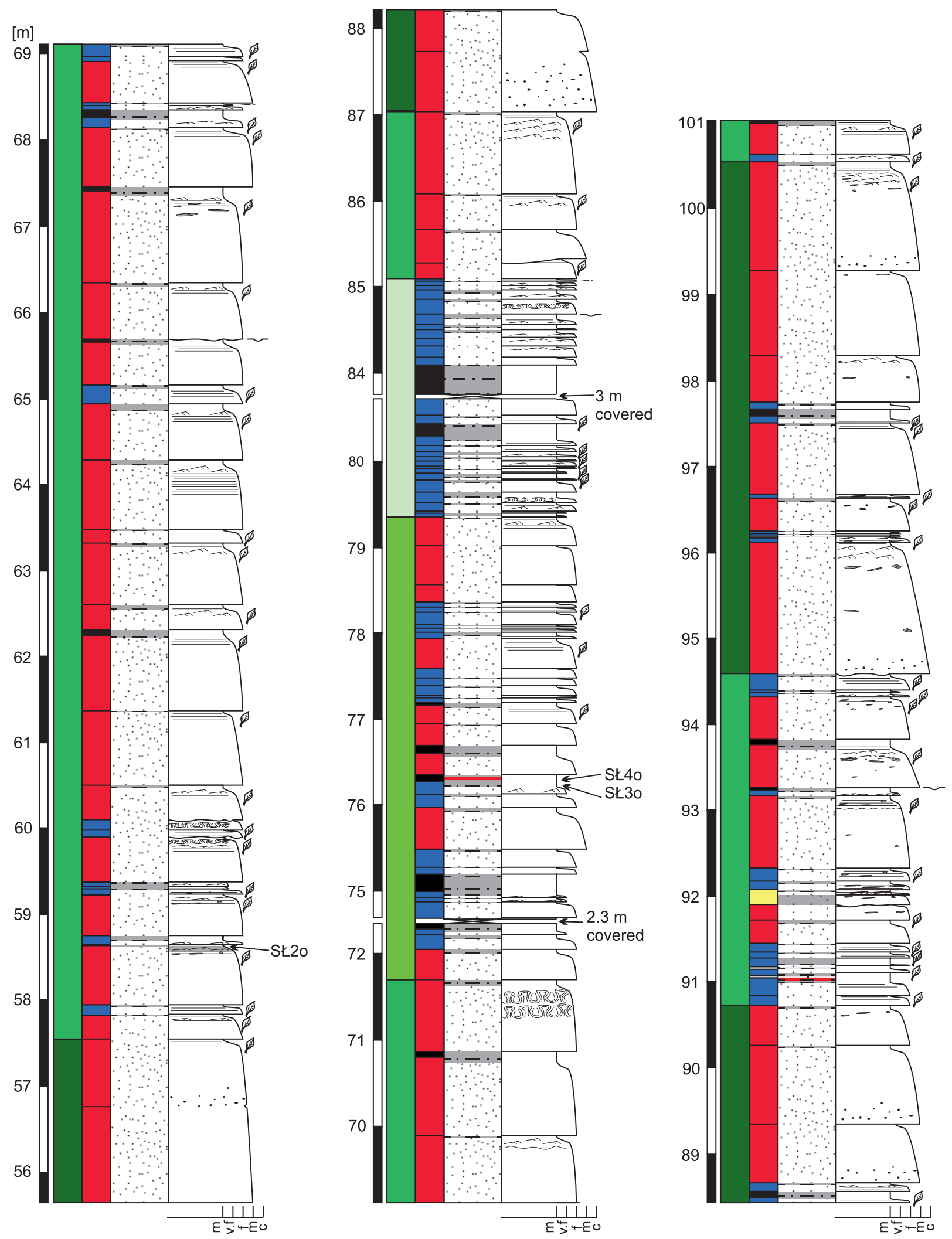

Fig. 3. Continuation from the previous page. 

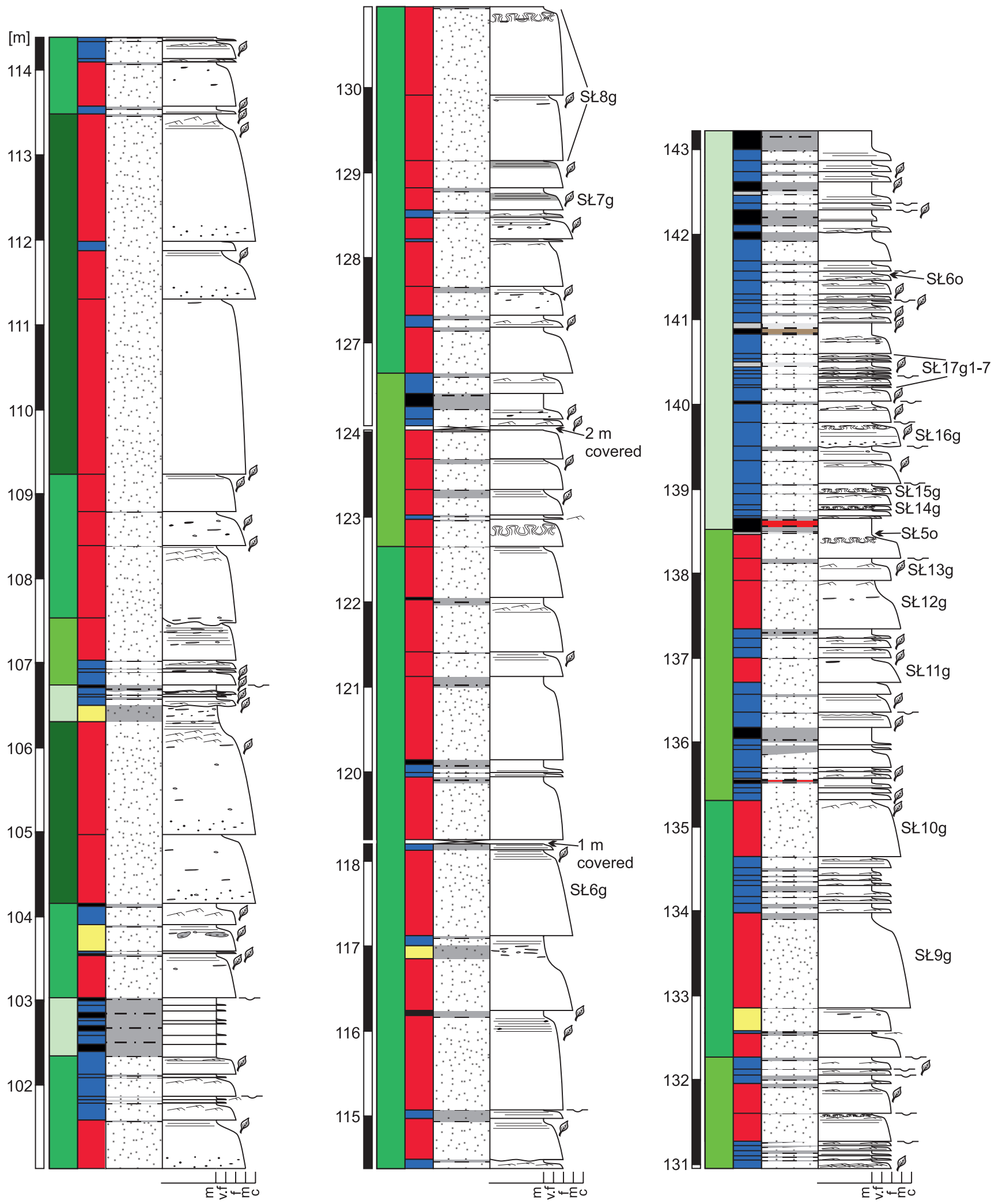

Fig. 3. Continuation from the previous page.

Sandstones are yellowish-white to rusty orange, calcareous quartz arenites. Most of them are poorly cemented, as is typical of the Ropianka Formation (Bromowicz, 1974). In addition to quartz, the sandstones contain grains of muscovite, glauconite, biotite, feldspar, pyrite, coal debris and plant detritus, as well as fragments of siliceous rocks, metamorphic green schists, grey mudstone and tests of agglutinated foraminifers. Petrographic studies (Bromowicz, 1974, 1986) show little regional variation in the mineral composition of sandstones in the Ropianka Formation. Current-ripple cross-lamination in sandstone beds indicates sediment transport direction generally from the north. 


\section{METHODS AND TERMINOLOGY}

The fieldwork focused on a detailed logging of the stratigraphic succession, with special attention given to the texture and primary structure of deposits, which allowed distinguishing a range of sedimentary facies. The descriptive sedimentological terminology is after Harms et al. (1975) and Collinson and Thompson (1982). Bed thickness categories are after Nichols (2009), with very thin $(<1 \mathrm{~cm})$, thin $(1-10 \mathrm{~cm})$, medium $(10-30 \mathrm{~cm})$, thick $(30-100 \mathrm{~cm})$ and very thick $(>100 \mathrm{~cm})$ classes. Statistical terminology is after Davis (2002).

Sedimentary facies are basic types of deposits distinguished on the descriptive basis of their bulk macroscopic characteristics (Walker, 1984). When dealing with episodic "event sedimentation" (sensu Dott, 1983), as in the present case of a flysch succession, the distinction of facies pertains to the products of individual sedimentary gravity-flow events and inter-flow episodes of background sedimentation (e.g., see Janbu et al., 2007). Differing assemblages of spatially and temporarily related facies are regarded as facies associations and considered to represent specific zones (subenvironments) of the sedimentary system. For simplicity, they are given interpretive genetic labels, but their descriptions are separated from interpretations in the text.

In order to determine vertical grain-size trends, particularly in massive sandstone beds, 80 sandstone samples were collected, disintegrated and processed by sieve analysis. Clay fraction was removed by washing on $0.05-\mathrm{mm}$ sieve. After drying, the clay-free sediment was passed through a column of standard sieves with apertures of $2,1,0.5$, $0.25,0.1$ and $0.063 \mathrm{~mm}$. In addition, eleven thin sections of fine-grained sandstones, marlstones and mudstones were analysed for mineral composition and grain-size characteristics. Thin sections perpendicular to bedding were used to measure the grain size by the conventional grid technique with an optical microscope. The longest dimension of 300 grains was measured in each thin section. This technique gives reasonably good estimates, but has its limitations (Johnson, 1994). For details of sedimentary and bioturbation structures, 24 rock slabs were collected, cut smooth and analysed macroscopically.

As many as 377 measurements of magnetic susceptibility were made, mainly on massive sandstone beds and in a $20-\mathrm{cm}$ interval, in order to recognize possible sub-macroscopic sediment grading. The measurements were taken with a ZM Instrument's SM30 magnetic susceptibility meter, using a resolution interpolation mode of $10^{-7}$ and a correction for the estimated air gap between the measuring device and the rock. However, the analytical procedure involves some assumptions and the dataset thus cannot be claimed to be free of systematic error.

Six mudstone samples were collected for micropalaeontological analysis of foraminifers in attempt to determine the biostratigraphic age of deposits. These samples were disintegrated with the Glauber salt and their foraminifer assemblages were analysed on quantitative basis.

\section{SEDIMENTARY FACIES}

Sedimentological analysis of the detailed outcrop log allowed distinguishing six sedimentary facies, F1-F6 (Fig. 4), on the basis of the deposit texture, structures, bed thickness, bed upward grain-size trend and mud-content change
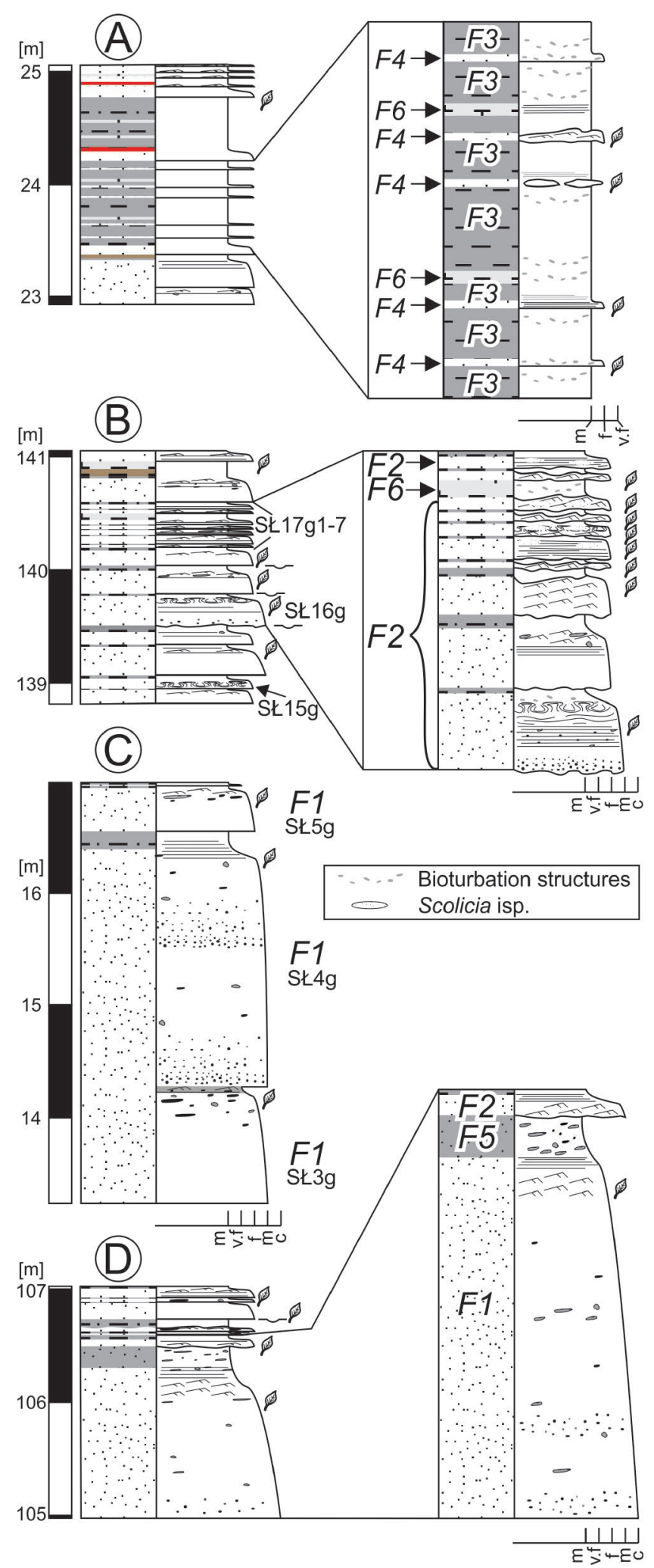

Fig. 4. Selected portions A-D of the outcrop $\log$ (log heights as in Fig. 3) showing examples of the sedimentary facies F1-F6. 
(Fig. 5), with an additional attempt to use also magnetic susceptibility signature. The distribution of facies in the stratigraphic log is shown in Figure 3. In this section of the article, the sedimentary facies are described and interpreted in terms of their mode of deposition.

\section{Facies F1}

Description: This facies consists of coarse- to very fine-grained, medium- to very thick-bedded sandstones (Figs 4, 6A). Sandstone beds are tabular on the outcrop scale, with sharp and visibly erosional lower boundaries. Sole marks occur, but the bed soles in most cases are poorly exposed. The majority of beds show normal grading with chaotically distributed pebble-sized coal and mudstone clasts, although some beds are non-graded or slightly inverse-graded (Fig. 5). Bed amalgamation is indicated by an abrupt grain-size increase or by the occurrence of lamination between consecutive massive bed divisions. The mud content of massive divisions ranges from 15 to $30 \mathrm{wt} . \%$ and reaches 40 wt.\% in some cases (Fig. 5).

Mudstone and coal clasts are largest and most abundant towards the top of massive bed divisions. They are oriented mainly parallel to bedding and tend to be concentrated in discrete horizons (Fig. 6B). Mudclasts are recognizably intraformational, reaching up to $20 \mathrm{~cm}$ in length. Some of the largest mudstone clasts include laminated siltstone
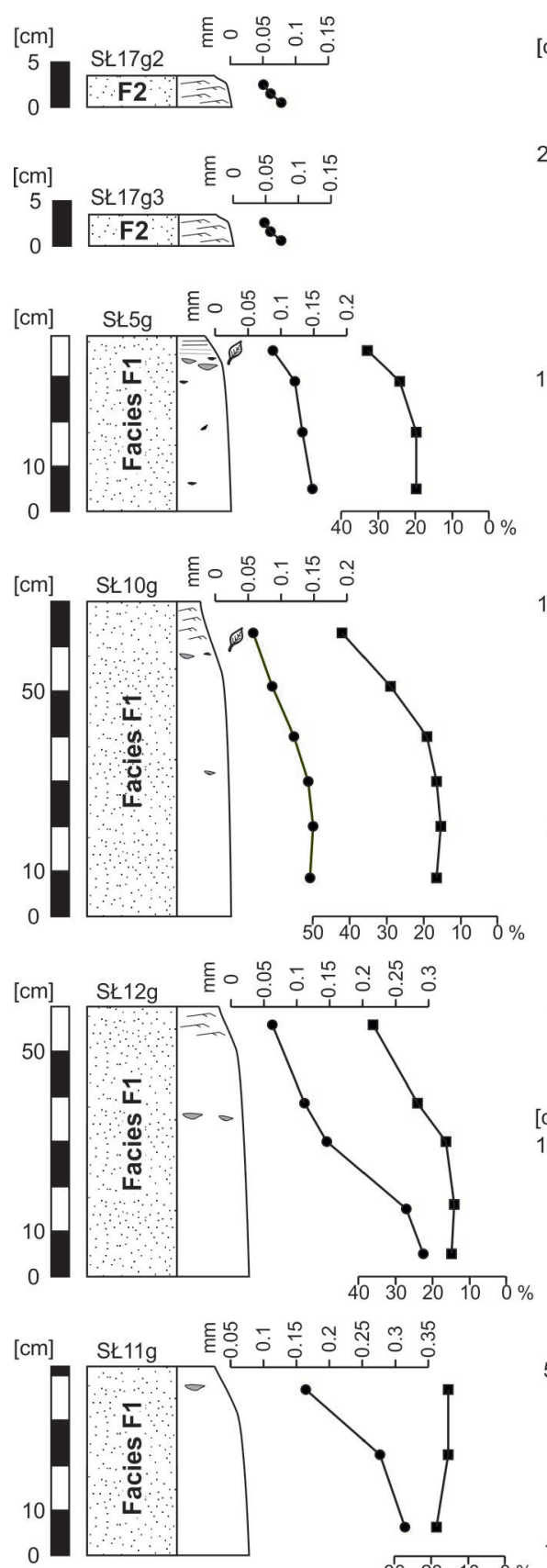
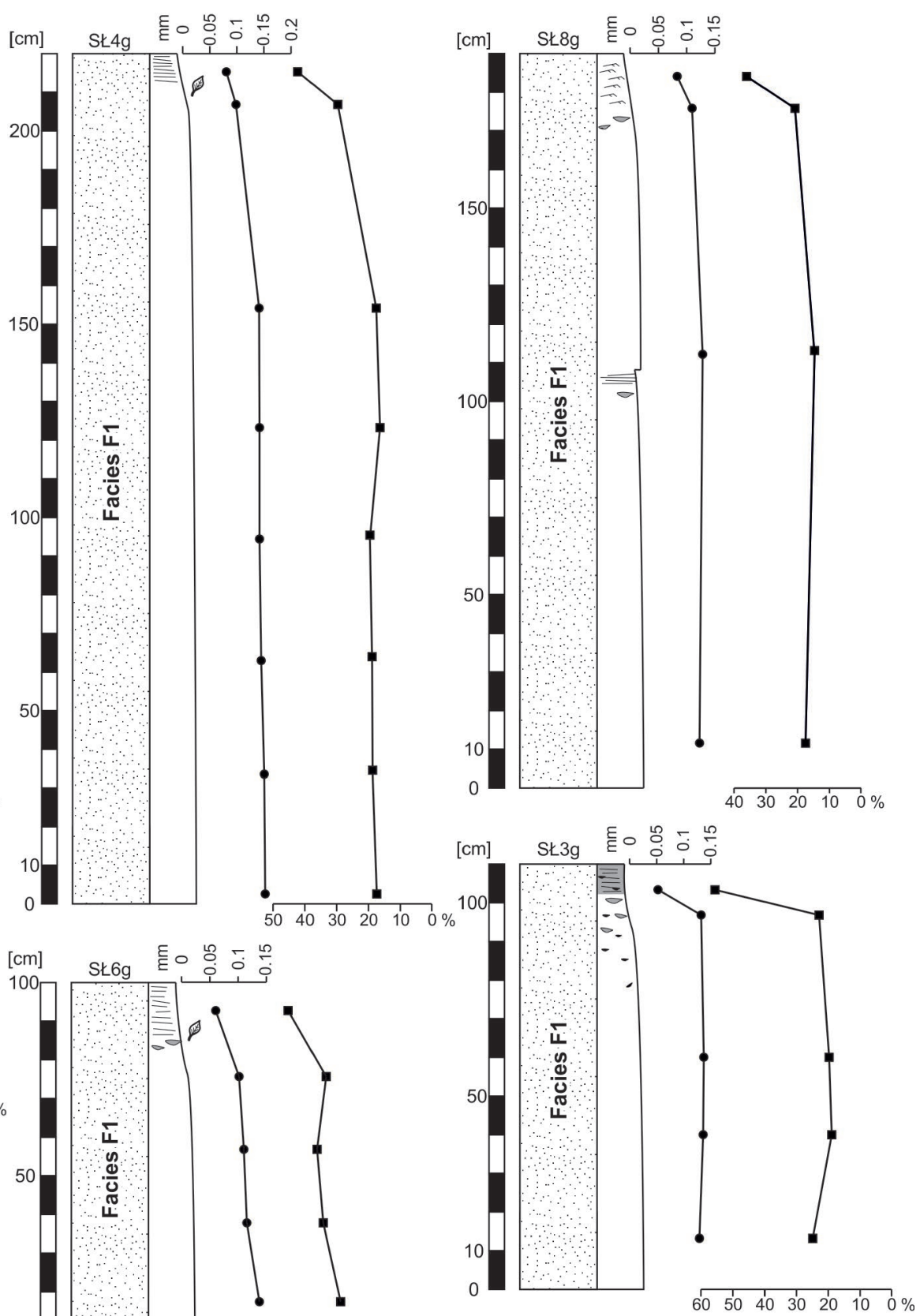

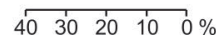

Fig. 5. Sediment grain-size and mud-content trends in the sandstone beds of facies F1, F2 and F5. The plot with circular dots indicates the sediment mean grain size $(\mathrm{mm})$ and the plot with square dotes indicates mud content (wt.\%). Continuation in the next pages. 
layers and seem to have been derived by erosion of the thin-bedded deposits of alternating facies F3 and F4 (described farther in the text). Bed top divisions show planar parallel lamination and/or ripple cross-lamination (Fig. 6C) and as such resemble beds of facies F4, but differ from the latter by capping gradationally a massive and generally much thicker bed division. The laminated top division often passes upwards into a siltstone/mudstone cap, although the latter is lacking in all cases of sandstone bed amalgamation. The upward increase of the amount of coalified plant detritus in many beds makes their top division an alternation of the brownish-black sandy bands with concentrated mudstone and coal clasts, 0.5 to $3 \mathrm{~cm}$ thick, and similar bands of laminated fine-grained 'clean' sand, often with some hydroplastic deformation (Fig. 6D).
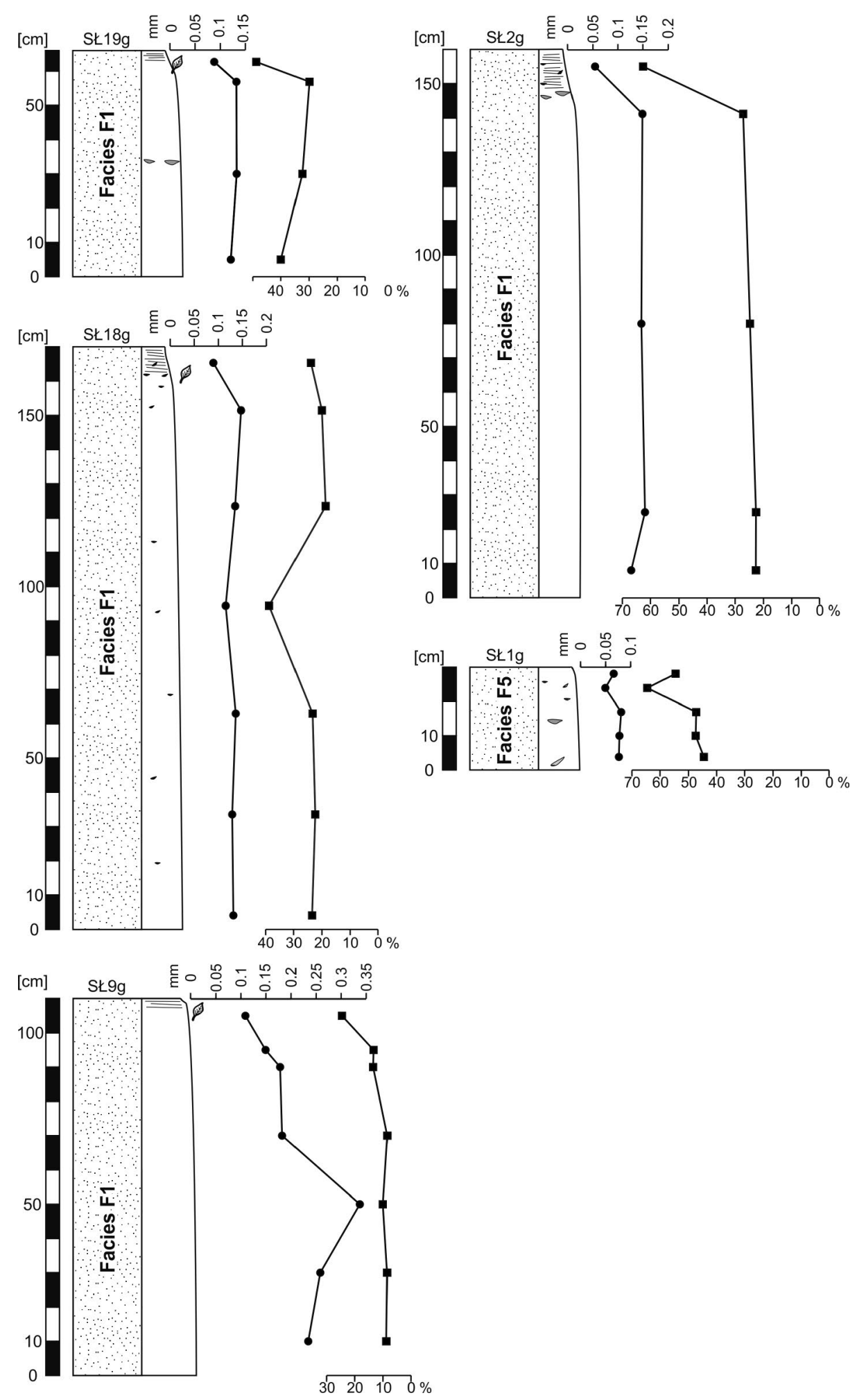

Fig. 5. Continuation from the previous page. 


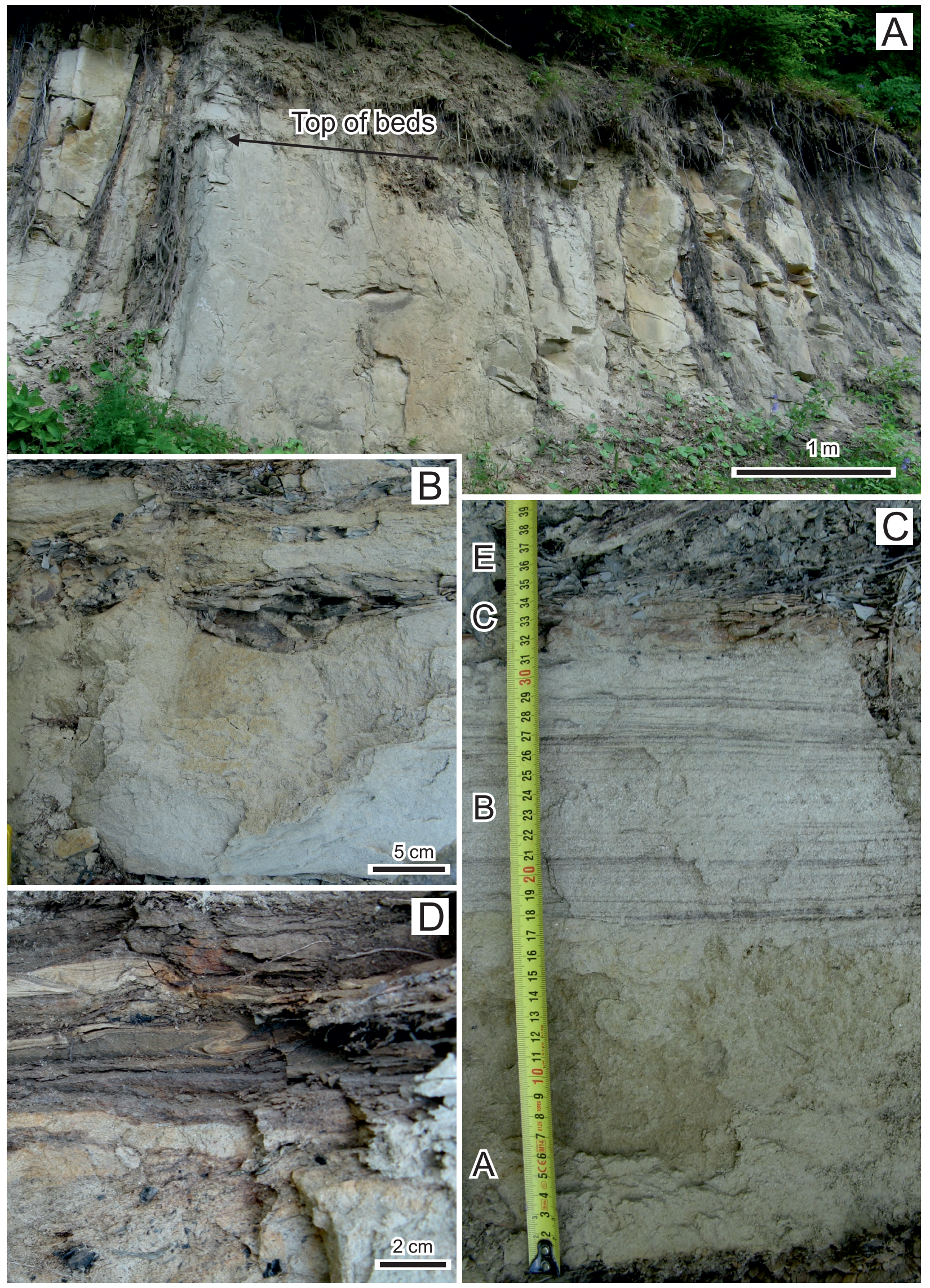

Fig. 6. Examples of the deposits of facies F1. A. Typical thick massive sandstone bed. B. Massive sandstone bed rich in bedding-parallel mudclasts at its top. C. Massive sandstone bed (A) with planar-laminated (B) to ripple cross-laminated (C) upper part capped with grey mudstone (E). D. The top part of a massive sandstone bed showing an alteration of dark brownish bands of massive sand rich in plant detritus and lighter-colour bands of parallel-laminated sand, with some hydroplastic deformation. 
Interpretation: The deposits of facies F1 are interpreted as products of high-density turbidity currents (sensu Lowe, 1982), inevitably capped with a laminated deposit of the final phase of low-density flow (cf. Talling et al., 2012). The thick massive lower division of the sandstone beds of facies F1 is comparable to Bouma's (1962) turbidite division $A$ and corresponds to the $S_{3}$ division of Lowe (1982). This massive division was formed by a rapid, non-tractional dumping of sand from a highly concentrated turbulent flow (see also Lowe, 1988; Allen, 1991). The occasional non-graded or weakly inverse-graded massive divisions may represent the high-density "moving-bed" part of a relatively thin flow (Vrolijk and Southard, 1997). Inverse grading may as well indicate a waxing flow (Kneller and Branney, 1995; Mulder et al., 2001).

As the rapid dumping hugely depleted the flow sediment load, a subsequent low-density phase of substrate reworking and tractional deposition occurred (Lowe, 1982), demarcated by grain-size fining and flow dissipation (see also Sumner et al., 2008). The planar parallel-laminated and/or ripple cross-laminated top division of sandstone beds corresponds to the Bouma turbidite divisions $\mathrm{B}$ and $\mathrm{C}$, respectively, and represents deposition from low-density tractional flow (Harms et al., 1975; see tractional division $\mathrm{T}_{t}$ of Lowe, 1982; also Best and Bridge, 1992; Leclair and Arnot, 2005). The fine-grained sandy to muddy capping, only occasionally preserved, comprises Bouma divisions $\mathrm{CD}(\mathrm{E})$ and resembles the independent thin beds of facies F2 (described farther in the text).

The emplacement of large intraformational mudclasts and plant debris, concentrated in the top part of massive bed divisions, occurred apparently along the rheological interface between the high-density lower part and low-density upper part of the flow (see Postma et al., 1988). The interface was probably fluctuating and generally rising, as suggested for the origin of dark/light turbidite banding by Lowe and Guy (2000). Such an upward concentration of mudclasts in discrete bands (Fig. 6D) is considered typical of high-density turbidity currents (Talling et al., 2012). Clasts dispersed randomly within the bed lower massive division were probably arrested therein by high sediment concentration and unable to float upwards to the flow rheological interface.

The bed-top banding indicates fluctuating sustained (long-duration) turbidity currents (Lowe and Guy, 2000), which - together with the abundance of plant detritus - may suggest delta-derived hyperpycnal flows (Mulder et al., 2001, 2002, 2003; Porębski and Warchoł, 2006; Zavala et al., 2012). No shallow-marine equivalents of the Ropianka Formation have thus far been documented and are rather unlikely to be preserved, but an occurrence of shelf-margin deltas in the high-relief narrow Skole Basin cannot be precluded.

\section{Facies F2}

Description: This facies consists of thin- to medium-bedded, medium- to very fine-grained sandstones (Fig. 4). Bed thicknesses are lower than in facies F1 and highly uneven on the outcrop scale, with occasional lateral pinch-outs.
Bed lower boundaries are invariably sharp and erosional, with abundant sole marks (where exposed). These sandstone beds show normal grading with plane-parallel lamination, often wavy, and with ripple cross-lamination (often climbing ripples) and frequent convolutions (Fig. 7A, B). Only some beds are massive in their basal part. Sand laminae commonly alternate between 'dark', rich in coalified plant detritus, and 'light' dominated by clean quartz sand. The dark laminae have a less steep dip than the light ones (Fig. 7C). Bed tops sporadically include small flaky mudstone chips, oriented parallel to the planar or cross-lamination. The sandstone beds are capped with a calcareous siltstone and mudstone, occasionally containing scattered coaly detritus and showing wispy planar lamination. Bioturbation abounds at the lower bed boundaries, represented mainly by Ophiomorpha isp. and Thalassinoides isp. The endichnial trace fossils often disturb or virtually destroy primary sedimentary structure, particularly in thin beds (Fig. 7A, B) where bedding-parallel Scolicia isp. dominates. Other recognizable trace fossils are Chondrites isp. and Planolites isp. Convolute lamination is common, involving deformation of trace fossils (Fig. 7A) and indicating an early post-depositional sediment disturbance by dewatering and some loading (cf. Dżułyński and Walton, 1965).

Interpretation: Facies F2 is interpreted as deposits of smaller-volume, high- to mainly low-density turbidity currents (sensu Lowe, 1982; see also Talling et al., 2012). Deposits of high-density flows, with a graded basal massive division, are subordinate. Most common are sandstone beds with the Bouma division B and/or C at the base, passing upwards into a muddy divisions $\mathrm{D}(\mathrm{E})$. Turbidites $\mathrm{T}_{\mathrm{CD}(\mathrm{E})}$ dominate, which indicates fully turbulent, tractional flows with a moderate to high (climbing ripples) rate of sediment suspension fallout (Ashley et al., 1982; Lowe, 1982; Talling et al., 2012).

\section{Facies F3}

Description: This facies consists of light- to dark-grey (locally greenish, yellowish or reddish brown) mudstones forming beds a few centimetres thick, rarely thicker than $5 \mathrm{~cm}$ (Figs 6C, 7C). Their lower boundary is mainly gradational, but their sand-covered top is sharp. These siliciclastic mudstone beds are slightly calcareous to non-calcareous and typically massive (non-laminated), bearing an admixture of muscovite, plant detritus, foraminifers, pyrite and small siderite concretions or diffuse sidertic impregnations. Trace fossils abound, but the only identifiable are Chondrites isp., Ophiomorpha isp., Thalassinoides isp. and Planolites isp. This sedimentary facies occurs at the top of sandstone-dominated bed packages, where it alternates with facies F2, F4 or F6 (Fig. 3) and sporadically also overlies beds of facies F1 and F5.

Interpretation: Similar muddy deposits in deep-sea facies models are commonly ascribed to a post-turbiditic hemipelagic to pelagic sedimentation (e.g., Bouma, 1962; Mutti and Ricci Lucchi, 1975; Stow and Shanmugam, 1980; Pickering et al., 1986). Beds with an upward decrease of 


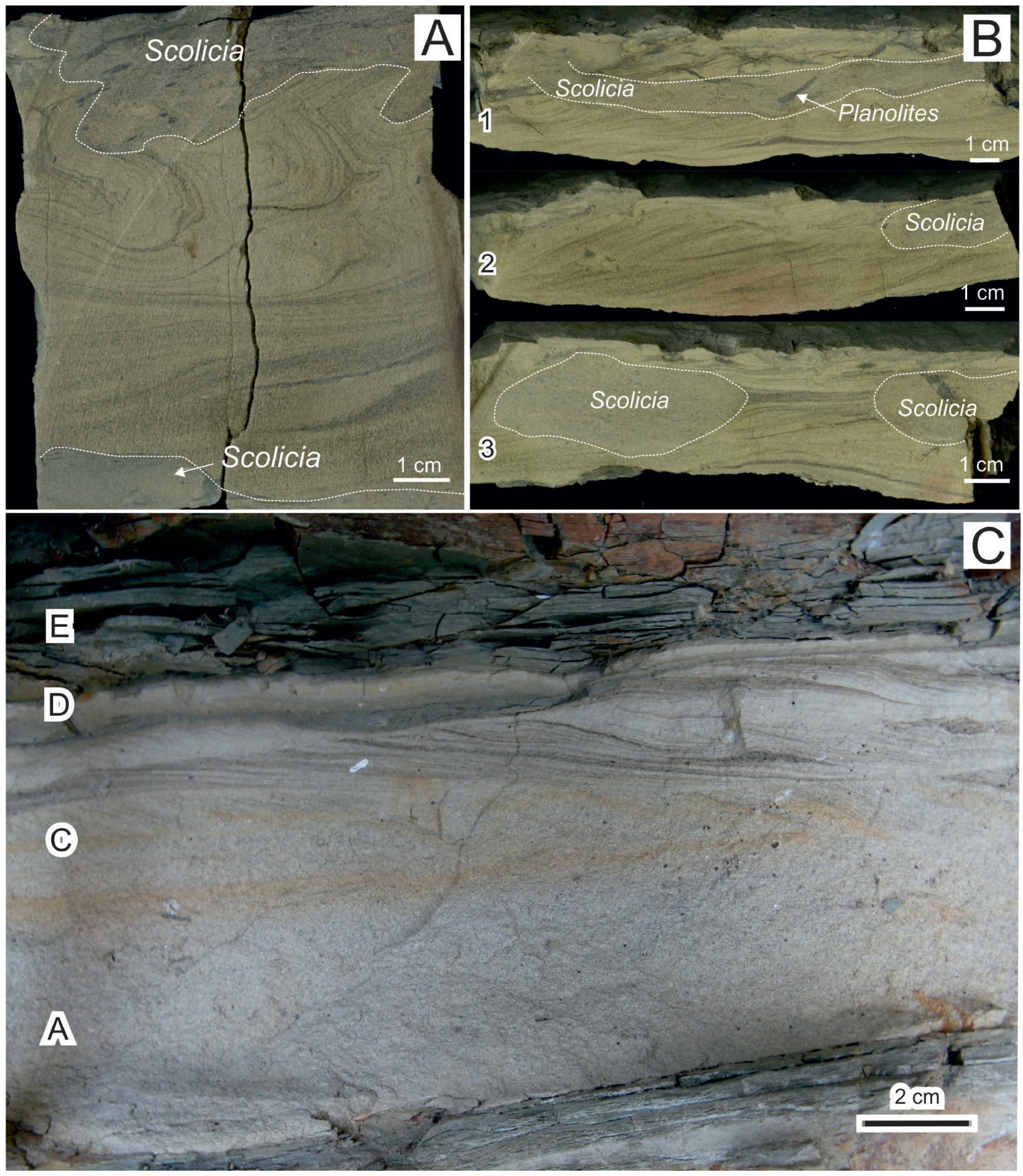

Fig. 7. Examples of the thin-bedded deposits of facies F2. A. Fully laminated and hydroplastically deformed bed with Scolicia traces. B. Three laminated beds (1-3) with trace fossils Scolicia and Planolites. C. Somewhat atypical turbidite bed $\mathrm{T}_{\mathrm{ACDE}}$.

calcium carbonate content suggest deposition around the lysocline. The calcareous lower part of these mudstone beds would be derived as turbidity-current suspension, whereas their non-calcareous upper part would represent basin background sedimentation. The abundance of trace fossils indicates well-oxygenated seafloor conditions.

\section{Facies F4}

Description: This facies is represented by beds of fine- to very fine-grained calcareous sandstone and siltstone, with thicknesses not exceeding $2 \mathrm{~cm}$ (Fig. 4). These beds only rarely pinch out laterally on the outcrop scale. Beds have 
sharp lower boundary and show normal grading (Fig. 8A) with mainly planar parallel and/or ripple cross-lamination. They are gradationally capped by a wispy-laminated mudstone rich in plant detritus (Fig. 8B). Many beds are cut across by the trace fossils Chondrites isp., Ophiomorpha isp., Thalassinoides isp. and Planolites isp., and some beds are totally bioturbated. Facies F4 occurs mainly as solitary beds in the upper part of sandstone-dominated bed packages, where it alternates with facies F2, F3, F6 and rarely F1.

Interpretation: This facies is interpreted as thin classical turbidites $\mathrm{T}_{(\mathrm{B}) \mathrm{CDE}}$ deposited by low-density turbidity currents (sensu Lowe, 1982). Their mode of deposition, with a gradual change from traction to suspension fallout, indicates waning surge-type flows. Such turbidites may represent: (1) the dilute tail of a bypassing larger and denser turbidity current; (2) the overbank spill-out of channelized flow; (3) the lateral pinch-out of a thinly spread turbidity current; or possibly (4) deep-water tidal or contour currents (Talling et al., 2012; Shanmugam, 2016). The first two possibilities are unlikely in the present case, because facies F4 is not associated with erosional bypass surfaces and there are no recognizable palaeochannels in the Słonne section. However, an evidence of palaeochannels is found in the advancing younger part of the Ropianka Formation (Łapcik, 2018), which renders the third possibility of unconfined flow spreading most probable, albeit also the last possibility cannot be precluded.

\section{Facies F5}

Description: This subordinate facies forms medium to thick beds of fine- to very fine-grained sandstone with chaotically dispersed plant detritus and randomly oriented clasts of mudstone and coal, up to large pebble size. Relatively high content of mud (Fig. 5) contributes to the dark grey colour of the deposit. Bed bases are flat to wavy and not recognizably erosional, and also their tops are flat to wavy (Fig. 9A). The beds are massive and lack grading, but tend to be capped by the Bouma turbidite divisions CDE (Fig. 9B) or are sporadically overlain sharply by facies $\mathrm{F} 1$ with sole marks.
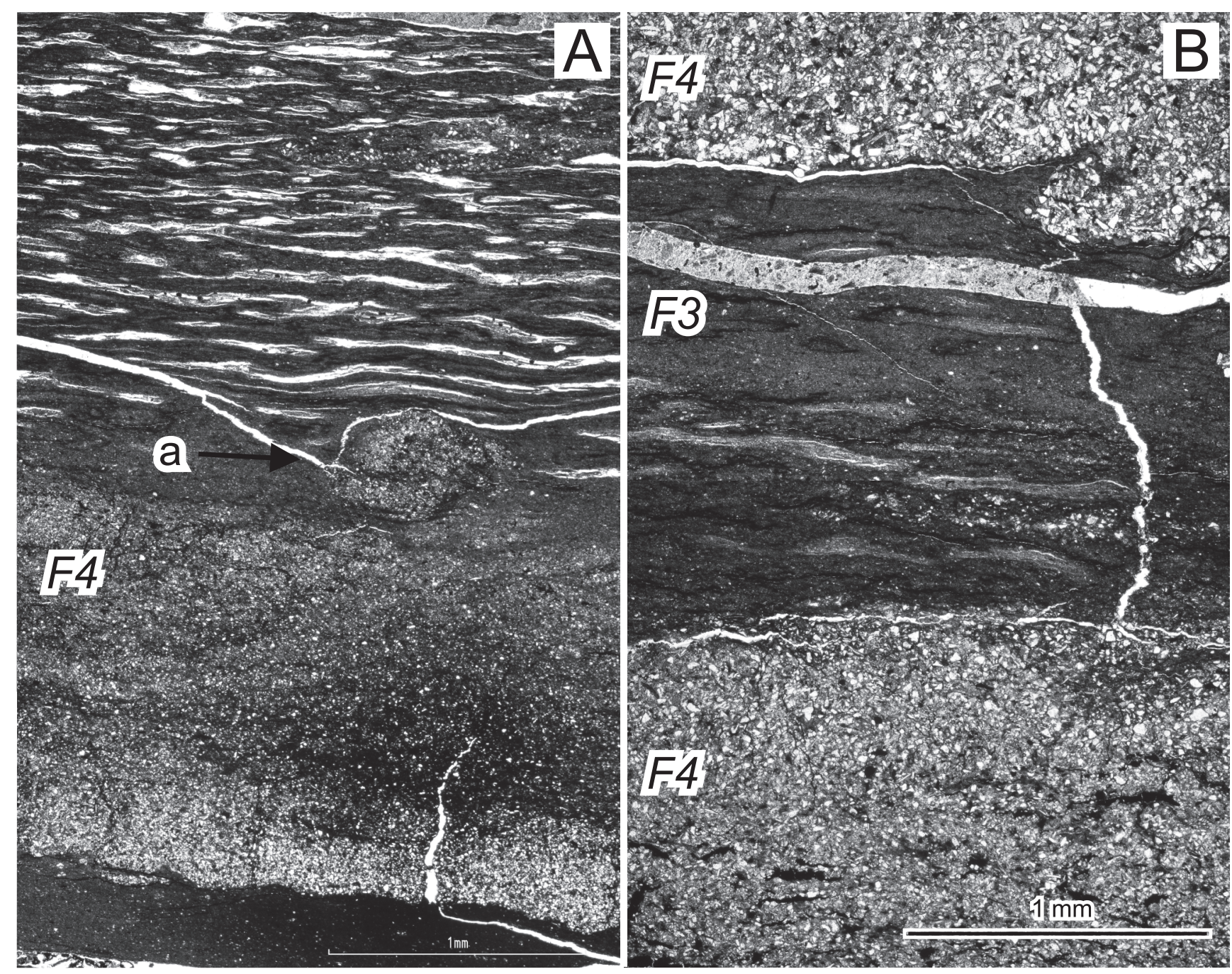

Fig. 8. Microstructure images of facies F3 and F4. A. Normal-graded very fine-grained sandstone with a high content of plant detritus passing upwards into a wispy-laminated mudstone with animal burrow (a) at their transition. B. Graded sandstone beds of facies F4, separated by a wispy-laminated mudstone of facies F3 with an upward-decreasing content of plant detritus. 

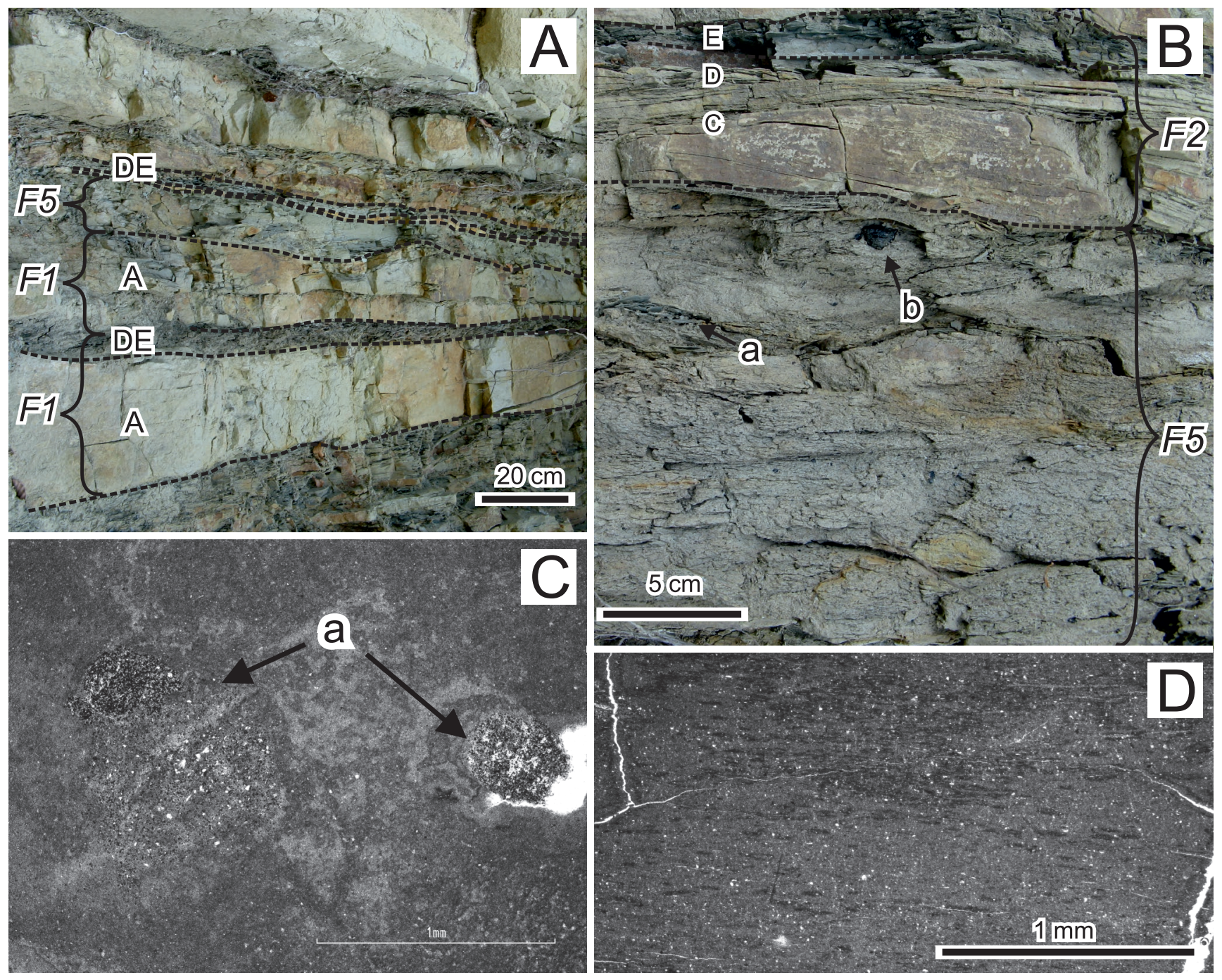

Fig. 9. Example beds of facies F5 and microstructures in facies F6. A. Massive sandstone bed of facies F1 with turbidite division A capped by laminated division D and grey mudstone division E, overlain by another massive bed of same facies, showing a wavy boundary with clast-rich massive debrite of facies F5 capped by laminated sandstone division D and grey mudstone division E. B. Sandy debrite of facies F5, with mudstone clasts (a) and coal debris (b), capped by turbidite divisions C, D and mudstone E. C. Massive marlstone of facies F6, with burrows filled with coarser sediment and faecal pellets (a). D. Patchy distribution of coalified plant detritus in facies F6 bed.

Interpretation: The deposits of facies F5 are interpreted as debrites emplaced by the en masse freezing of non-turbulent dense flow (cf. Breien et al., 2010; Strzeboński, 2015). From the bed characteristics, it is unclear as to whether the debris flow was a parental mass movement, diluted at the top (turbidite cap $\mathrm{T}_{\mathrm{CDE}}$ ), or whether it was spawned by a large turbidity current excessively charged with mud and plant detritus (with the $\mathrm{T}_{\mathrm{CDE}}$ cap as low-density flow relic). Either of these possibilities seems viable (cf. Lowe, 1982; Fisher, 1983; Postma et al., 1988; Marr et al., 2001). Similar, albeit much thinner, massive basal divisions in some of the turbidite beds of facies F1 and F5 suggest basal densification of flow with suppression of turbulence by an erosional incorporation of mud and plant detritus. On the other hand, it cannot be precluded that the CDE capping is a signature of deep-water tidal or contour currents (cf. Strzeboński, 2015; Shanmugam, 2016).

\section{Facies F6}

Description: This facies is rare and represented by thin beds of bluish-grey marlstone (Fig. 4), poor in quartz and bioclasts, dominated by micrite with patchily distributed plant detritus (Fig. 9D). The lower bed boundary is sharp to gradational, whereas the top is a gradual transition into darker-grey mudstone. Some beds show plane-parallel wispy lamination, but the majority are massive. Bioturbation structures abound, with Chondrites isp., Planolites isp. and Ophiomorpha isp. burrows are invariably filled with a darker and coarser sediment (Fig. 9C). Tunnels of Ophiomorpha are locally branched and $3-5 \mathrm{~mm}$ in diameter. This marlstone facies occurs mainly at the top of sandstone-dominated bed packages, where it alternates with facies F2, F3 and F4.

Interpretation: The occurrence of marlstones in alternation with non-calcareous pelagic to hemipelagic mudstones 
(facies F3) is rather unusual and, therefore, facies F6 is interpreted as representing allodapic limestones, or calciturbidites $\mathrm{T}_{\mathrm{DE}}$ (e.g., Flügel, 2010). The mode of deposition by a highly dilute turbidity current would be similar as for facies F4, with the parallel wispy lamination representing Bouma division $\mathrm{D}$. The apparent scarcity of lamination in facies F4 beds is partly due to sediment bioturbation.

\section{MAGNETIC SUSCEPTIBILITY}

The measurements of magnetic susceptibility (MS) were conducted mainly for massive sandstone beds or bed divisions to check if they show any particular upward trend that might help distinguish facies and interpret their origin. The underlying theoretical expectation was that the massive sandstones deposited by turbulent flows, as opposed to those deposited by non-turbulent flows, might show a subtle, macroscopically unrecognizable upward decrease in grain size and increase in mud content.

A comparison of the apparent macroscopic trends in grain size and mud content with the corresponding MS trends of the massive beds of facies F1 (Fig. 10) shows common discrepancies. The inconsistent and highly variable MS values of some beds may be due to a non-uniform compositional mixing of sediment dumped by flow as turbidite division A and possibly to the irregular 'cloudy' development of siderite cement. This interpretive notion is supported by the MS measurements taken laterally along the same bed horizons, which show similarly variable values and confirm lack of any consistent upward trend. The vertical distribution of detrital magnetic minerals correlates poorly with the trend of the host-sediment grain size and mud content, because these heavy mineral grains have specific settling velocities, commonly vary in size and hence may be associated with various grain-size fractions and occur irregularly at various levels within the deposit. For the same reason, perhaps, even the markedly different turbidite divisions $\mathrm{A}, \mathrm{B}$ and $\mathrm{C}$ failed to show any systematic differences in their MS values (Fig. 10).

The MS measurements have thus shed some light on the distribution of magnetic mineral grains in the deposits, but helped little in the recognition of the sediment mode of deposition and in distinguishing between turbidites and debrites. These analytical results are reported herein chiefly as an instructive cautionary note for researchers who may be contemplating the use of this petrophysical technique in flysch studies.

\section{SEDIMENTARY FACIES ASSOCIATIONS}

The sedimentary facies in the outcrop stratigraphic successions appear to be grouped into packages, several metres thick, ranging from thick-bedded and sandstone-dominated to thin-bedded and mudstone-dominated (Fig. 3). Four types of such packages have been distinguished as facies associations on the basis of their facies composition, the mean value and variance of bed thicknesses and the net/ gross sandstone percentage (see data summary in Tab. 1).
Table 1.

Quantitative summary of the characteristics of depositional lobe facies associations in the Słonne section (see lobe model in Fig. 11A).

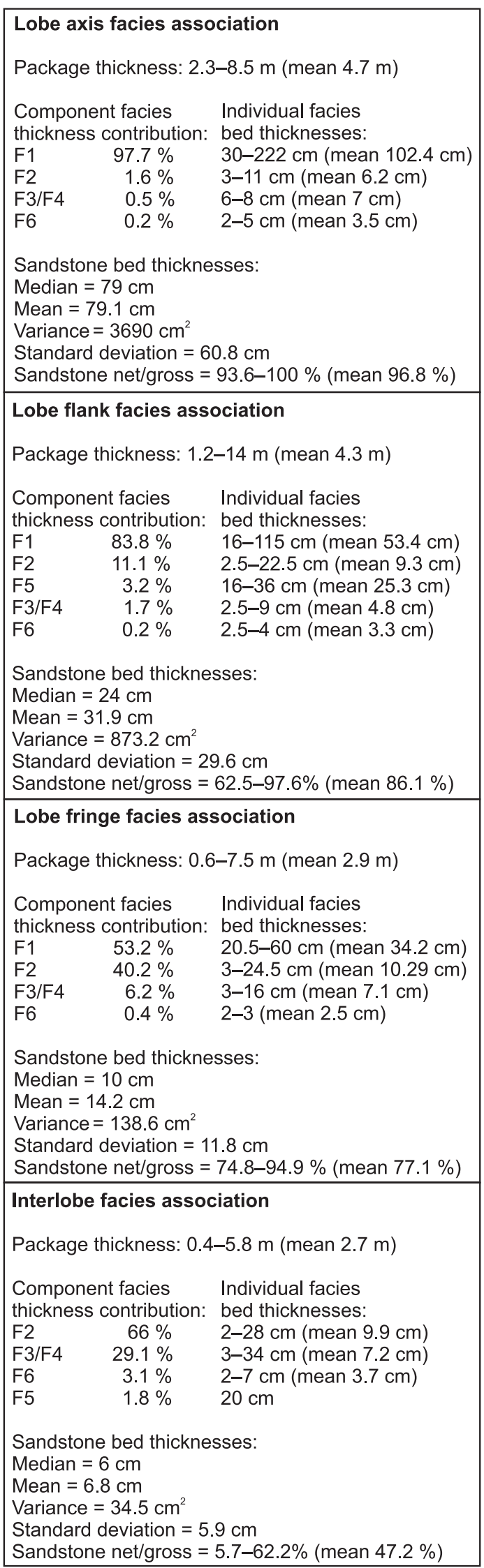



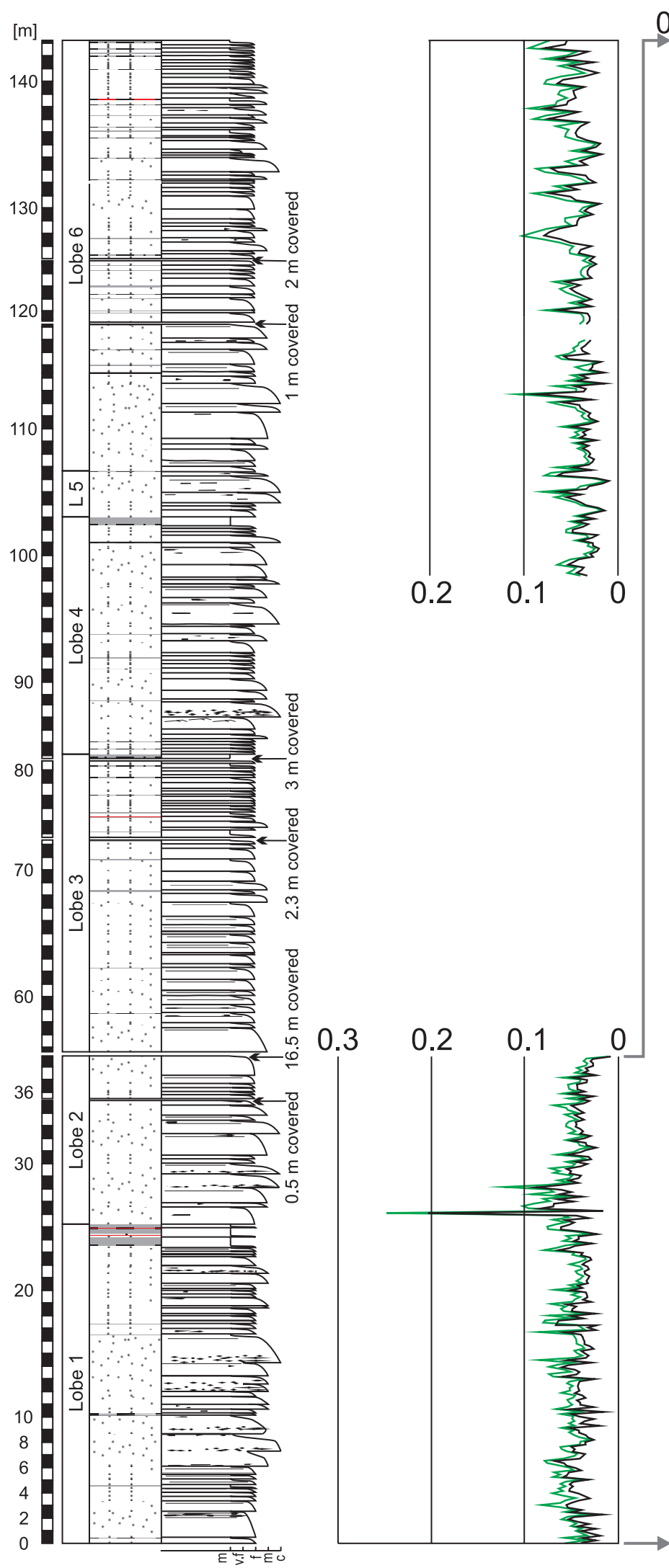

0.3

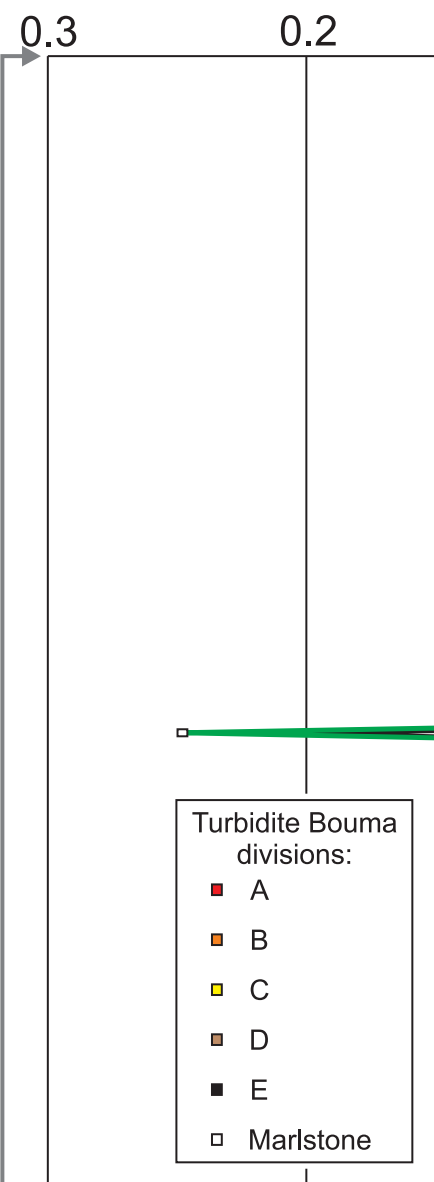

0.1 0

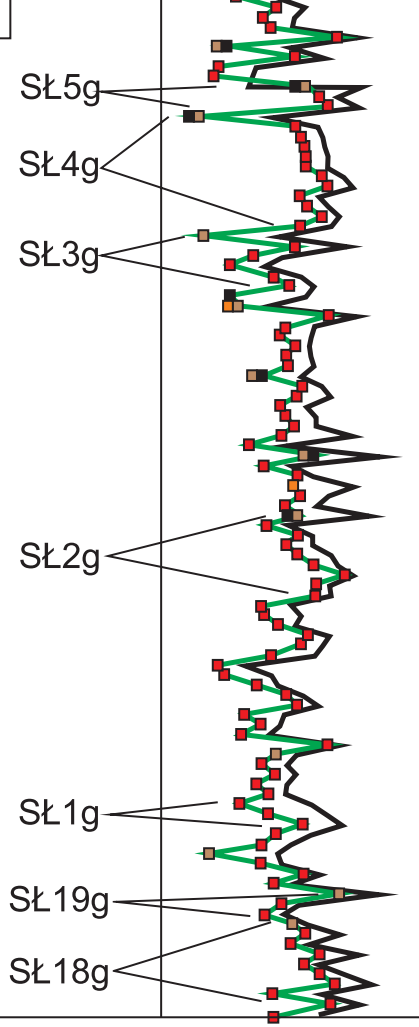

Fig. 10. Simplified sedimentological log with the corresponding magnetic susceptibility log (green curve - uncorrected raw data; black curve - data corrected for an estimated air gap between the measuring device and the rock). Note that the log to the far right is an enlarged detailed version of the MS log from the lower part of the succession. 


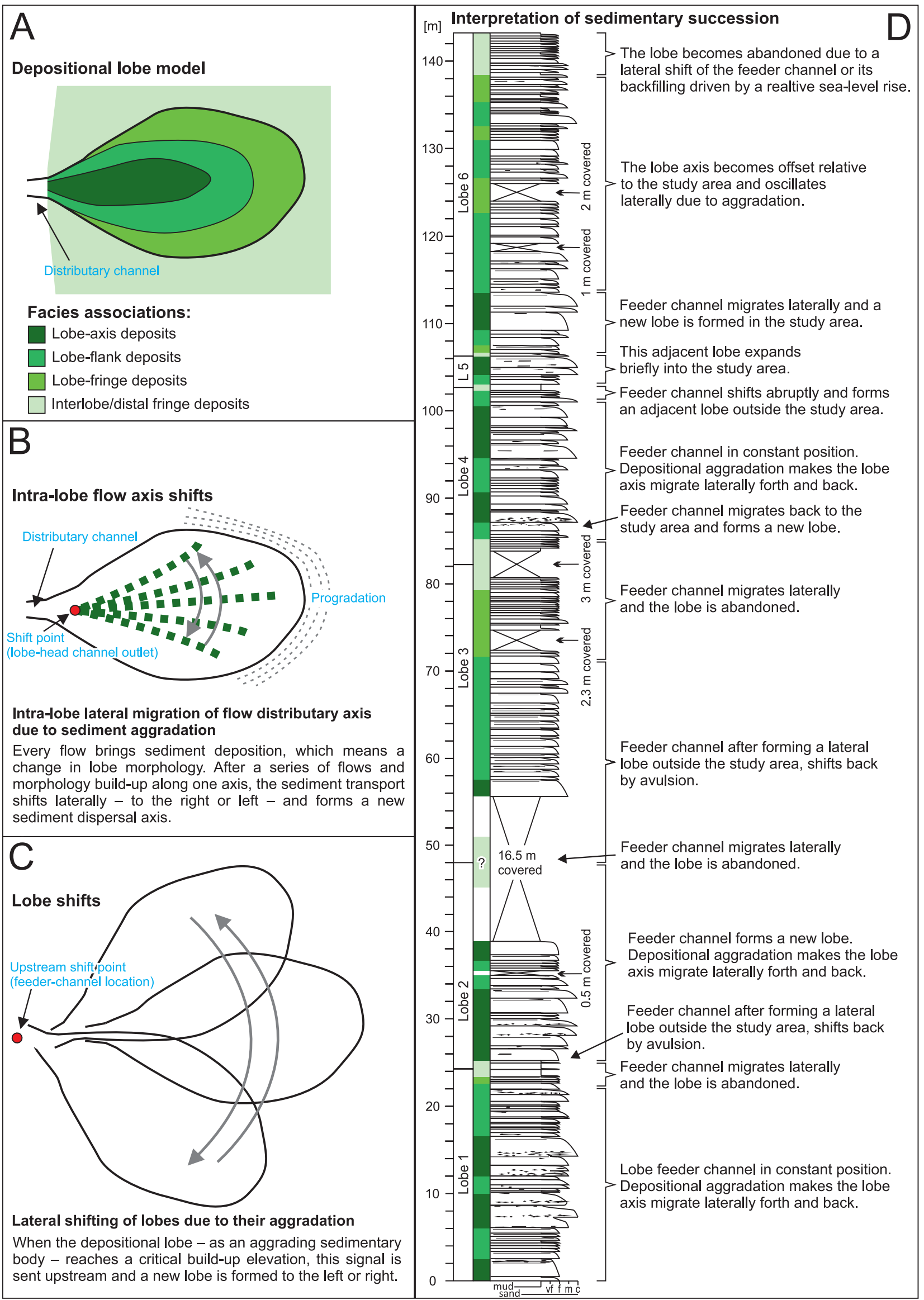

Fig. 11. Interpretive summary of the Słonne section. A. Model of depositional lobe with its facies associations. B. Depositional lobe growth by lateral migration of its sediment dispersal axis. C. Depositional lobe lateral shifts by feeder-channel switching. D. Interpretation of the sedimentary succession in terms of dynamic stratigraphy. 
The sandstone beds in the whole succession are tabular on the outcrop scale and the facies associations show mainly transitional boundaries, with no evidence of deep scouring and possible palaeochannels. Classical sheet-like turbidites dominate and typical channel-fill facies (e.g., see Pickering et al., 1995; Janbu et al., 2007) are absent. These characteristics suggest a sedimentary system of channel-fed depositional turbiditic lobes formed by unconfined flows (cf. Mutti and Ricci Lucchi, 1972; Shanmugam, and Moiola, 1988, 1991; Pickering et al., 1995; Mulder, 2011; Shanmugam, 2016). These four facies associations distinguished in the outcrop profile are considered to represent different morphodynamic zones of a depositional lobe (Tab. 1). They are characterized and interpretively compared in this section of the article.

\section{Lobe-axis facies association}

Description: These bed assemblages are $2.3-8.5 \mathrm{~m}$ thick, have a sandstone net/gross of $\sim 94 \%$ to $100 \%$ and are dominated ( $\sim 98 \%$ thickness) by the sandstone facies F1 with only minor contribution of facies F2, F3/F4 and F6 (Tab. 1). Facies F1 reaches here its greatest bed thicknesses, in the range of 30-222 cm and averaging $102 \mathrm{~cm}$. The overall variance of bed thicknesses in this facies assemblage is the highest, with a standard deviation $(S D)$ of $\sim 61 \mathrm{~cm}$, whereas the median $(M d)$ and mean $(M)$ are equal. The latter relationship indicates a perfectly normal, symmetrical bed-thickness frequency distribution and implies that $\sim 70 \%$ of the component beds are in the thickness range of $M \pm 1 S D, \sim 95 \%$ of beds are in the range of $M \pm 2 S D$ and $\sim 100 \%$ of beds are in the range of $M \pm 3 S D$.

Interpretation: This facies assemblage, as the most sandstone-rich and thickest-bedded, is interpreted to represent the axial sediment-dispersal zone of a turbiditic depositional lobe (cf. Mutti and Normark, 1987; Pickering et al., 1995; Stow and Mayall, 2000; Deptuck et al., 2008; Prélat et al., 2009; Mulder, 2011; Grundvåg et al., 2014; Marini et al., 2015).

\section{Lobe-flank facies association}

Description: These bed assemblages are 1.2-14 m thick, have a sandstone net/gross of $\sim 63 \%$ to $98 \%$ and are similarly dominated ( $\sim 84 \%$ thickness) by the sandstone facies F1, but with a contribution of facies F5 and also greater contribution of facies F2 and F3/F4 (Tab. 1). The beds of facies F1 are thinner, in the range of $16-115 \mathrm{~cm}$ and averaging $53 \mathrm{~cm}$. The bulk variance of bed thicknesses in this facies assemblage is much lower, with a standard deviation of $\sim 30 \mathrm{~cm}$. The mean $(32 \mathrm{~cm})$ is higher than median $(24 \mathrm{~cm})$, which indicates a positively skewed bed-thickness frequency distribution (i.e., some excess of thicker beds).

Interpretation: This type of facies assemblage is the second richest in sandstones and resembles the previous one in being dominated by facies F1, but is distinctly thinner bedded and shows a nearly $20 \%$ contribution of finer-grained facies, notably including F5. These characteristics suggest that this facies association is probably a lateral, off-axis equivalent of the previous one and represents depositional lobe flank (cf. Shanmugam and Moiola, 1991; Pickering et al., 1995; Deptuck et al., 2008; Grundvåg et al., 2014).

\section{Lobe-fringe facies association}

Description: The facies assemblages of this third type are only $0.6-7.5 \mathrm{~m}$ thick (mean $\sim 3 \mathrm{~m}$ ), have a sandstone net/ gross of $75 \%$ to $95 \%$ and consist in nearly equal proportion of facies F1 and of the finer-grained facies F2, F3/F4 and F6 (Tab. 1). The beds of facies F1 are here even thinner, averaging $34 \mathrm{~cm}$, whereas those of facies $F 2$ and F3/F4 are slightly thicker. Overall, bed thicknesses are more than half-thinner than in the previous facies association, with a mean of $14 \mathrm{~cm}$ and median of $10 \mathrm{~cm}$. The bulk variance of bed thicknesses is also much lower, with a standard deviation of only $12 \mathrm{~cm}$. The mean slightly higher than median indicates likewise a slight positive skewness of bed-thickness frequency distribution.

Interpretation: The markedly lower bed thicknesses, lower sandstone net/gross and strikingly lower proportion of facies F1 suggest that this third type of facies association probably represents the thin featheredge fringe zone of depositional lobes (cf. Pickering et al., 1995; Deptuck et al., 2008; Prélat et al., 2009; Grundvåg et al., 2014).

\section{Interlobe facies association}

Description: This fourth type of facies assemblages is only 0.4-5.8 m thick (mean $2.7 \mathrm{~m}$ ), has a low sandstone net/gross of $\sim 6 \%$ to $62 \%$ (mean $47 \%$ ) and strikingly lacks component facies F1 (Tab. 1). Dominant are facies F2 (66\%) and F3/F4 (29\%). The beds here are thinnest, with their mean thickness $(\sim 7 \mathrm{~cm})$ nearly equal to median $(6 \mathrm{~cm})$ and with a low standard deviation of $6 \mathrm{~cm}$.

Interpretation: This thinly bedded association of finegrained facies lacks the lobe signature facies $F 1$ and is thought to represent the interlobe zone, or most distal lobe fringe, of the turbiditic depositional system (cf. Pickering et al., 1995; Deptuck et al., 2008; Prélat et al., 2009; Grundvåg et al., 2014).

\section{PALAEONTOLOGICAL EVIDENCE}

The deposits in the Słonne outcrop section show sporadic to abundant animal burrows and contain small benthic foraminifers. The identified trace fossils include Planolites isp., Ophiomorpha isp., Chondrites isp., Scolicia isp. and Thalassinoides isp. Deep-water turbiditic depositional lobes, with the frequent incursions of large and small sediment-gravity flows and a relatively high sedimentation rate, provide a generally stressful habitat for benthic organisms (MacEachern et al., 2010; Uchman and Wetzel, 2012). The evidence of benthic life in the present case is limited mainly to the thin-bedded and finer-grained facies F2-F6. However, the amount of plant detritus (potential nutrient) delivered 
by sediment gravity flows was apparently much higher than the nutrient supplied by hemipelagic and pelagic suspension fallout, and thereby the optimal time for seafloor colonization was when the local rate of sedimentation declined with the lateral switching of depositional lobe (Fig. 11C).

Samples collected for micropalaeontological analysis (Fig. 3) showed low-diversity assemblages of agglutinated foraminifers. As representative and relatively rich, sample SŁ3o (log height 76.2 m, Fig. 3) contained: Nothia excelsa (Grzybowski), Psammosiphonella discreta (Brady), Rhizammina sp., Saccammina grzybowskii (Schubert), Placentammina placenta (Grzybowski), Hyperammina dilatata Grzybowski, Ammodiscus cf. cretaceus (Reuss), Ammodiscus peruvianus Berry, Ammodiscus tenuissimus Grzybowski, Glomospira irregularis (Grzybowski), Caudammina excelsa (Dylążanka), Caudammina gigantea (Geroch), Caudammina ovula (Grzybowski) emend Geroch, 1960, Caudammina ovuloides (Grzybowski), Hormosinelloides guttifer (Brady), Hormosina velascoensis (Cushman), Kalamopsis grzybowskii (Dylążanka), Subreophax scalaris (Grzybowski), Paratrochamminoides div.sp., Haplophragmoides cf. suborbicularis (Grzybowski), Recurvoides indet., Gerochammina obesa Neagu and Dorothia crassa (Marsson). These foraminifers indicate water depth below the local lysocline, which is consistent with the deposition of mainly non-calcareous pelagic to hemipelagic mudstones. The occurrence of agglutinated foraminifera with carbonate cement, such as Dorothia crassa, suggests a temporal depth slightly above lysocline. Seafloor aggradation probably combined with lysocline fluctuations, and the lysocline in the Late Cretaceous could be up to $\sim 50 \%$ shallower than today (Lyle, 2003; Rea and Lyle, 2005), perhaps at a mid-bathyal sea depth.

Analysis of foraminifer assemblages indicates a late Cretaceous age (Campanian-Maastrichtian) of the deposits, with a similarity to the Wiar Member of the Ropianka Formation (Fig. 2). This evidence compares well with the lithological similarity of the deposits to Rajchel's (1989) stratigraphic Complex I.

\section{DYNAMIC STRATIGRAPHY}

The four facies associations described in the previous section (Tab. 1) are thus considered to represent different morphodynamic zones of a turbiditic depositional lobe (Fig. 11A). They alternate with one another in the stratigraphic succession (Fig. 3), and these vertical changes at the Słonne intra-basinal locality are attributed to the lateral migration (Fig. 11B) and wholesale shifting (Fig. 11C) of successive depositional lobes. The Late Cretaceous Skole Basin in its Polish segment had a WNW-ESE trend (Kováč et al., 2016), and the southward directions of sediment transport - roughly perpendicular to the basin axis - suggests transversely-built depositional lobes unconfined by the basin topography, although often skewed towards the east or west by their expansion in the basin. The stepwise 'in-sequence' upward changes of lobe directly adjacent zones (Fig. 11A) are attributed to the lobe lateral migration by the shifting of its sediment dispersal axis (Fig. 11B). The abrupt 'out-of-sequence' changes, with the appearance of interlobe facies association, are ascribed to a wholesale shift of the depositional lobe due to an upstream change of its feeder-channel position (Fig. 11C).

The logic behind this morphodynamic interpretation (see Mutti and Ricci Lucchi, 1972; Mutti and Sonnino, 1981; Shanmugam, and Moiola, 1988, 1991; Pickering et al., 1995; Deptuck et al., 2008; Prélat et al., 2009; Shanmugam, 2016) is that - as the depositional lobe aggrades along its axis of sediment dispersal - the dispersal axis inevitably shifts sideways and hence the lobe migrates laterally (Fig. 11B). As the whole lobe gradually builds up in this way, its feeder channel eventually shifts laterally by avulsion and a new lobe forms (Fig. 11C), onlapping sideways the previous one while growing.

The Słonne stratigraphic section (Fig. 3) is then interpreted to represent the turbiditic system's local morphodynamic changes on both intra-lobe and interlobe depositional scale (Fig. 11B, C). Based on the in-sequence and out-of-sequence upward changes of facies associations, six successive vertically stacked depositional lobes are distinguished in the stratigraphic succession with a tentative reconstruction of their depositional morphodynamics (see Fig. 11D and interpretation therein). The thicknesses of the inferred lobes and their inter-lapping flanks are comparable to those reported from elsewhere by other authors (e.g., Deptuck et al., 2008; Prélat et al., 2009; Bernhardt et al., 2011; Grundvåg et al., 2014; Marini et al., 2015). The depositional lobes were likely elongate (Fig. 11A), but their dimensions probably varied, depending on the lobe growth time, and are difficult to estimate from a single outcrop section. For a radial lobe with surface inclination of $\sim 0.3^{\circ}$ (i.e., topographic gradient $\sim 0.005$, typical for small radial turbiditic fans; Bouma et al., 1985) and a mid-lobe axial thickness of $\sim 10 \mathrm{~m}$ (Tab. 1), the lobe estimated width would be $\sim 2 \mathrm{~km}$ and length perhaps $\sim 3.5 \mathrm{~km}$. The lateral shingling of lobes (Fig. 11C) would render their complex at least 3 times wider, without necessarily extending significantly its length, while possibly skewing the lobes and merging their adjacent complexes.

The facies associations differ markedly from one another (Tab. 1), but individually show consistent facies composition and bed thicknesses, which suggests that the growth rate of the successive depositional lobes composed of these associations was similar. However, the actual time span of lobe growth and the rate of its lateral migration may have varied, as the 'compensational' offset stacking of lobes would depend upon the turbiditic system's net equilibrium profile and the seafloor topographic accommodation (cf. Mutti and Sonnino, 1981; Deptuck et al., 2008; Picot et al., 2016; Shanmugam, 2016). Therefore, some of the lobes grew at the study locality longer than other lobes, and yet some other lobes extended laterally into this area only briefly (Fig. 11D).

Deposits interpreted as interlobe facies association demarcate the successive depositional lobes stacked upon one another in the outcrop section. In the hypothetical interpretation of the succession (Fig. 11D), lobe 1 formed with a stable position of its feeder channel and with the sediment aggradation making the lobe axis migrate laterally forth and back (log interval 0-24 m, lobe base unexposed). 
The build-up of lobe 1 eventually caused its feeder channel to shift laterally by avulsion and the lobe was abandoned. After forming a new lobe outside the study area, the feeder channel had shifted back and formed lobe 2 (log interval 24-48 m). Similar shifts of feeder channel resulted in lobes 3 and 4 (log intervals $48-82 \mathrm{~m}$ and $82-102 \mathrm{~m}$, respectively). Lobe 5 formed outside the study area, but expanded briefly into it by the lobe axis lateral migration (log interval 102$-106 \mathrm{~m}$ ). The feeder channel then switched back and formed the thick lobe 6 (log interval 106-144 m), with the lobe axis oscillating laterally while migrating sideways until the lobe abandonment.

This stratigraphic interpretation refers to an autogenic morphodynamics of the depositional system, with the intra-lobe migration of dispersal axis and lobe aggradation (Fig. 11B) leading to the lateral switching of distributary channel (Fig. 11C). However, it cannot be precluded that at least some of the lobe abandonment phases were caused by a relative sea-level rise, with a decline of sediment supply and the system bulk retreat. The Campanian-Maastrichtian period had witnessed 4 major $(>75 \mathrm{~m}), 4$ moderate $(25-$ $-75 \mathrm{~m})$ and 5 minor $(<25 \mathrm{~m})$ eustatic changes (Snedden and Liu, 2010). It is possible that at least these larger changes had an impact in the Skole Basin and that the thicker interlobe packages (Fig. 11D) are transgressive outer lobe-fringe deposits. The biostratigraphic dating is insufficient to allow time correlations. On the other hand, the basin was tectonically active and a similar impact of tectonic forcing could possibly come into play.

\section{IMPLICATIONS FOR THE SKOLE BASIN}

The sediment to the deep-water Skole Basin was derived from its northern passive margin (Bromowicz, 1974), with the mud-rich deposits of the basin "external" (northern) zone representing the basin slope and the sand-rich deposits in the "internal" (southern) zone, such as the Wiar Member of the Ropianka Formation, probably representing some baseof-slope or basin-floor turbiditic fans (cf. Kotlarczyk, 1978, 1988; Kotlarczyk and Leśniak, 1990). The northern passive margin evolved from immature to mature in the Cretaceous to Oligocene (Salata and Uchman, 2013). Kotlarczyk and Leśniak (1990) have recognized three main fairways of sand transport from the north in the Oligocene Menilite Formation (Fig. 2). The spatial distribution of thick-bedded sandstones in the Ropianka Formation shows a similar pattern (e.g., Gucik et al., 1980; Salata and Uchman, 2013). The occurrence of Lower Cretaceous black mudstone clasts in the Ropianka Formation (Kotlarczyk, 1988) indicates canyons or valleys deeply incised in the basin older deposits already in the Campanian time, when the main fairways were probably established.

According to Bromowicz (1974), the transport direction during the deposition of Ropianka Formation was mainly from the north and northwest (Fig. 1), and only the oldest deposits of this formation, in the SE part of the Skole Nappe, show palaeocurrent directions from the east and southeast. This evidence, supported by the present study, puts in question the earlier notions of sand dispersal along the basin axis, based on the spatial distribution of sandstones (Gucik et al., 1980; Burtan et al., 1981; Jurkiewicz and Woiński, 1981; Kotlarczyk, 1988; Woiński, 1994; Nescieruk et al., 1995). The Campanian-Early Maastrichtian base-of-slope depositional lobe complexes may have merged laterally at the stages of their maximum expansion in the narrow basin, giving the false impression of a narrow sand depocentre parallel to the basin axis. The south-built lobe complexes would likely become skewed eastwards or westwards in the narrow basin according to its floor local accommodation (cf. Rajchel, 1989), but this would not mean that the main sediment dispersal was longitudinal, parallel to the basin axis.

The high amount of plant detritus in the Słonne section (Fig. 3) suggests a deltaic or paralic source of sediment supply. The deeply incised fluvial feeder canyons or valleys would inevitably host bayhead deltas, from which also hyperpycnal flows may have been issued (as suggested by some of the beds of facies F1). The fluctuating supply of siliciclastic and carbonate sediment indicates an involvement of both fluvio-deltaic and carbonate sources. Their interplay is highlighted by the occurrence of marlstone beds containing plant detritus (Fig. 9D). The relatively small and sporadic contribution of facies F6 suggests that the sediment sourcing system only occasionally involved a calcareous source, which may indicate episodic carbonate production on basin-margin narrow shelf, perhaps driven by the Campanian eustatic sea-level rises (cf. Snedden and Liu, 2010).

\section{CONCLUSIONS}

This first detailed study of the Ropianka Formation in the Słonne outcrop section along river San has indicated from lithological and micropalaeontological similarities that the sedimentary succession exposed there corresponds regionally to the formation's Wiar Member of CampanianMaastrichtian age.

The sedimentary succession, more than $140 \mathrm{~m}$ thick, exposed in the Słonne section is interpreted as a deep-marine complex of turbiditic depositional lobes. The study has revealed its sedimentary anatomy by recognizing six component facies of sediment gravity-flow deposits and their stratigraphic grouping into four facies associations - interpreted as deposits of the lobe dispersal-axis zone, lateral flank zone and featheredge fringe zone, as well as an interlobe outer-fringe zone.

The component facies associations of the succession have been individually characterized and compared on a semi-quantitative basis, which gave a detailed insight into the succession's sedimentary heterogeneity.

Six depositional lobes stacked upon one another have been recognized in the succession, and their vertical stacking pattern has been hypothetically interpreted in terms of dynamic stratigraphy based on the upward succession of facies associations.

The stratigraphic arrangement of facies associations is attributed to autogenic morphodynamic changes in the depositional system, but it cannot be precluded that also eustatic and local tectonic forcing came into play. 
This case study sheds more light on the sedimentary environment, sediment sourcing system and spatial depositional pattern in the Late Cretaceous Skole Basin, where the aggrading seafloor apparently oscillated around the lysocline depth, which at that time could be mid-bathyal.

\section{ACKNOWLEDGEMENTS}

The study was funded by the Jagiellonian University. Ewa Malata (Jagiellonian University) helped in the identification of foraminifers. Alfred Uchman (Jagiellonian University) and Wojciech Nemec (Bergen University) offered discussions and improved the manuscript, which was formally reviewed with helpful comments by Juraj Janočko (Technical University of Košice) and Michał Warchoł (Statoil Research Centre in Bergen).

\section{REFERENCES}

Allen, J. R. L., 1991. The Bouma division A and the possible duration of turbidity currents. Journal of Sedimentary Research, 61: 291-295.

Ashley, G. M., Southard, J. B. \& Boothroyd, J. C., 1982. Deposition of climbing-ripple beds: a flume simulation. Sedimentology, 29: 67-79.

Bernhardt, A., Jobe, Z. R. \& Lowe, D. R., 2011. Stratigraphic evolution of a submarine channel-lobe complex system in a narrow fairway within the Magallanes foreland basin, Cerro Toro Formation, southern Chile. Marine and Petroleum Geology, 28: 785-806.

Best, J. \& Bridge, J., 1992. The morphology and dynamics of low amplitude bedwaves upon upper stage plane beds and the preservation of planar laminae. Sedimentology, 39: 737-752.

Bouma, A. H., 1962. Sedimentology of Some Flysch Deposits: A Graphic Approach to Facies Interpretation. Elsevier, Amsterdam, $168 \mathrm{pp}$.

Bouma, A. H., Normark, W. R. \& Barnes, N. E., 1985. Submarine Fans and Related Turbidite Systems. Springer Verlag, New York, $351 \mathrm{pp}$.

Breien, H., De Blasio, F. V., Elverhøi, A., Nystruen, J. P. \& Harbitz, C. B., 2010. Transport mechanisms of sand in deep-marine environments - insights based on laboratory experiments. Journal of Sedimentary Research, 80: 975-990.

Bromowicz, J., 1974. Facial variability and lithological character of Inoceramian Beds of the Skole-Nappe between Rzeszów and Przemyśl. Prace Geologiczne, 84: 1-83. [In Polish, with English summary.]

Bromowicz, J., 1986. Petrographic differentiation of source areas of Ropianka Beds east of Dunajec River (Outer Carpathians, Poland). Annales Societatis Geologorum Poloniae, 56: 253-276. [In Polish, with English summary.]

Bukowy, S., 1957a. Remarks on the sedimentation of the Babica Clays. Rocznik Polskiego Towarzystwa Geologicznego, 26: 147-155. [In Polish, with English summary.]

Bukowy, S., 1957b. Węgiel kamienny w Karpatach brzeżnych. Przeglad Geologiczny, 5: 577-578. [In Polish.]

Bukowy, S. \& Geroch, S., 1957. On the age of exotic conglomerates at Kruhel Wielki near Przemyśl (Carpathians). Rocznik
Polskiego Towarzystwa Geologicznego, 26: 297-329. [In Polish, with English summary.]

Burtan, J., Golonka, J., Oszczypko, N., Paul, Z. \& Ślączka, A., 1981. Mapa geologiczna Polski, 1:200 000, arkusz Nowy Sącz. Wydawnictwa Geologiczne, Warszawa. [In Polish.]

Burzewski, J., 1966. Les marnes à Baculithes sur le fond de la lithostratigraphie des à Inocérames dans les Carpathes de skibas". Zeszyty Naukowe AGH, Geologia, 7: 89-115. [In Polish, with French summary.]

Clark, J. D. \& Pickering, K. T., 1996. Architectural elements and growth patterns of submarine channels: application to hydrocarbon exploration. American Association of Petroleum Geologists Bulletin, 80: 194-220.

Collinson, J. D. \& Thompson, D. B., 1982. Sedimentary Structures. Allen and Unwin, London, 207 pp.

Davis, J. C., 2002. Statistics and Data Analysis in Geology. 3rd ed., John Wiley \& Sons, New York, 638 pp.

Deptuck, M. E., Piper, D. J. W., Savoye, B. \& Gervais, A., 2008. Dimensions and architecture of Late Pleistocene submarine lobes off the northern margin of East Corsica. Sedimentology, 55: 869-898.

Dott, R. H., Jr., 1983. Presidential address: Episodic sedimentation - How normal is average? How rare is rare? Does it matter? Journal of Sedimentary Petrology, 53: 5-23.

Dżułyński, S., Kotlarczyk, J. \& Ney, R., 1979. Podmorskie ruchy masowe w basenie skolskim. In: Kotlarczyk, J. (ed.), Poziomy $z$ olistostromami $w$ Karpatach przemyskich. Materiaty Terenowej Naukowej Konferencji w Przemyślu: Stratygrafia formacji z Ropianki (fm). Powielarnia AGH, Przemyśl, pp. 17-27. [In Polish.]

Dżułyński, S., Książkiewicz, M. \& Kuenen, P. H., 1959. Turbidites in flysch of the Polish Carpathian Mountains. Geological Society of America Bulletin, 70: 1089-1118.

Dżułyński, S. \& Smith, A. J., 1964. Flysch facies. Rocznik Polskiego Towarzystwa Geologicznego, 34: 245-266.

Dżułyński, S. \& Walton, E. K., 1965. Sedimentary Features of Flysch and Greywackes. Developments in Sedimentology, 7: $1-272$.

Fisher, R. V., 1983. Flow transformations in sediment gravity flows. Geology, 11: 273-274.

Flügel, E., 2010. Microfacies of Carbonate Rocks. Analysis, Interpretation and Application. Springer-Verlag, Berlin, 984 pp.

Gedl, E., 1999. Lower Cretaceous palynomorphs from the Skole Nappe (Outer Carpathians, Poland). Geologica Carpathica, 50: 75-90.

Golonka, J., Gahagan, L., Krobicki, M., Marko, F., Oszczypko, N. \& Ślączka, A., 2006. Plate-tectonic evolution and paleogeography of the Circum-Carpathian region. In: Golonka, J. \& Picha, F. J. (eds), The Carpathians and their foreland: Geology and hydrocarbon resources. American Association of Petroleum Geologists, Memoir, 84: 11-46.

Gradstein, F., Ogg, J., Schmitz, M. \& Ogg, G., 2012. The Geological Time Scale 2012. Elsevier, Oxford, 1176 pp.

Grundvåg, S. A., Johannessen, E. P., Hansen, W. H. \& PlinkBjörklund, P., 2014. Depositional architecture and evolution of progradationally stacked lobe complexes in the Eocene Central Basin of Spitsbergen. Sedimentology, 61: 535-569. 
Gucik, S., Paul, Z., Ślączka, A. \& Żytko, K., 1980. Mapa geologiczna Polski 1:200 000, arkusz Przemyśl, Kalników. Wydawnictwa Geologiczne, Warszawa. [In Polish.]

Harms, J. C., Southard, J. B., Spearing, D. R. \& Walker, R. G., 1975. Depositional Environments as Interpreted from Primary Sedimentary Structures and Stratifcation Sequences. Lecture Notes, SEPM Short Course No. 2. Society of Economic Paleontologists and Mineralogists, Dallas, $161 \mathrm{pp}$.

Janbu, N. E., Nemec, W., Kırman, E. \& Özaksoy, V., 2007. Facies anatomy of a channelized sand-rich turbiditic system: the Eocene Kusuri Formation in the Sinop Basin, north-central Turkey. In: Nichols, G., Paola, C. \& Williams, E. A. (eds), Sedimentary Environments, Processes and Basins - A Tribute to Peter Friend. International Association of Sedimentologists Special Publication, 38, 457-517.

Jednorowska, A., 1957. On the microfauna of the Inoceramus Beds within the "Skiba" region in the vicinity of Słonne and Wara. Acta Geologica Polonica, 7: 303-320. [In Polish, with English summary.]

Johnson, M. R., 1994. Thin section grain size analysis revisited. Sedimentology, 41: 985-999.

Johnson, S. D., Flint, S., Hinds, D. \& De Ville Wickens, H., 2001. Anatomy, geometry and sequence stratigraphy of basin floor to slope turbidite systems, Tanqua Karoo, South Africa. Sedimentology, 48: 987-1023.

Jurkiewicz, H. \& Woiński, J., 1981. Mapa geologiczna Polski, 1:200 000, arkusz Mielec. Wydawnictwa Geologiczne, Warszawa. [In Polish.]

Kneller, B. C. \& Branney, M. J., 1995. Sustained high-density turbidity currents and the deposition of thick massive sands. Sedimentology, 42: 607-616.

Kotlarczyk, J., 1978. Stratigraphy of the Ropianka Formation or of Inoceramian beds in the Skole Unit of the Flysch Carpathians. Prace Geologiczne, 108: 1-75. [In Polish, with English summary.]

Kotlarczyk, J., 1988. Przewodnik LIX Zjazdu PTG w Przemyślu. Wydawnictwa AGH, Kraków, 298 pp. [In Polish.]

Kotlarczyk, J., Jerzmańska, A., Świdnicka, E. \& Wiszniowska, T., 2006. A framework of ichtyofaunal ecostratigraphy of the Oligocene-Early Miocene strata of the Polish Outer Carpathian Basin. Annales Societatis Geologorum Poloniae, 76: $1-111$.

Kotlarczyk, J. \& Leśniak, T., 1990. Lower Part of the Menilite Formation and Related Futoma Diatomite Member in the Skole Unit of the Polish Carpathians. Instytut Geologii i Surowców Mineralnych AGH, Wydawnictwo Akademii Górniczo-Hutniczej, Kraków, 74 pp. [In Polish, with English summary.]

Kotlarczyk, J. \& Śliwowa, M., 1963. On knowledge of the productive Carboniferous formations in the substratum of the eastern part of the Polish Carpathians. Przeglad Geologiczny, 11: 268-272. [In Polish, with English summary.]

Kováč, M., Plašienka, D., Soták, J., Vojtko, R., Oszczypko, N., Less, G., Ćosović, V., Fügenschuh, B. \& Králiková, S., 2016. Paleogene palaeogeography and basin evolution of the Western Carpathians, Northern Pannonian domain and adjoining areas. Global and Planetary Change, 140: 9-27.

Kropaczek, B., 1917. Kleine Beiträge zur Geologie der nördlichen Karpaten Mittelgaliziens. Sprawozdania Komisji Fizjograficznej Akademii Umiejętności, 51: 106-146. [In Polish, with German summary.]
Książkiewicz, M., 1962. Geological Atlas of Poland. Stratigraphic and Facial Problems. Cretaceous and Early Tertiary in the Polish External Carpathians, 13. Wydawnictwa Geologiczne, Warszawa. [In Polish, with English summary.]

Książkiewicz, M., 1972. Karpaty. In: Budowa geologiczna Polski, 4. Tektonika Volume 3, Wydawnictwa Geologiczne, Warszawa, pp. 121-196. [In Polish.]

Łapcik, P., 2018. Sedimentary processes and architecture of Upper Cretaceous deep-sea channel deposits: a case from the Skole Nappe, Polish Outer Carpathians. Geologica Carpathica, 69: 71-88.

Łapcik, P., Kowal-Kasprzyk, J. \& Uchman, A., 2016. Deepsea mass-flow sediments and their exotic blocks from the Ropianka Formation (Campanian-Paleocene) in the Skole Nappe: a case study of the Wola Rafałowska section (SE Poland). Geological Quarterly, 60: 301-316.

Leclair, S. F. \& Arnott, R. W. C., 2005. Parallel lamination formed by high-density turbidity currents. Journal of Sedimentary Research, 75: 1-5.

Leszczyński, S., 1981. Ciężkowice Sandstones of the Silesian Unit in the Polish Carpathians: a study of coarse-clastic sedimentation in deep water. Annales Societatis Geologorum Poloniae, 51: 435-502.

Lowe, D. R., 1982. Sediment gravity flows: II. Depositional models with special reference to the deposits of high-density turbidity currents. Journal of Sedimentary Petrology, 52: 279-297.

Lowe, D. R., 1988. Suspended-load fallout rate as an independent variable in the analysis of current structures. Sedimentology, 35: 765-776.

Lowe, D. R. \& Guy, M., 2000. Slurry-flow deposits in the Britannia Formation (Lower Cretaceous), North Sea: a new perspective on the turbidity current and debris flow problem. Sedimentology, 47: 31-70.

Lyle, M. W., 2003. Neogene carbonate burial in the Pacific Ocean. Paleoceanography, 18: PA1059.

MacEachern, J. A., Pemberton, S. G., Gingras, M. K. \& Bann, K. L., 2010. Ichnology and facies models. In: James, N. P. \& Dalrymple, R. W. (eds), Facies Models 4. Geoscience Canada, St. John's, pp. 19-59.

Malata, T., 2001, Jednostka skolska na E od Rzeszowa. Posiedzenia Naukowe Państwowego Instytutu Geologii, 57: 60-63. [In Polish.]

Malata, T. \& Poprawa, P., 2006. Evolution of the Skole Subbasin. In: Oszczypko, N., Uchman, A. \& Malata, E. (eds), Rozwój paleotektoniczny basenów Karpat zewnętrznych. Institute of Geological Sciences, Jagiellonian University, Kraków, pp. 101-110. [In Polish, with English abstract.]

Marini, M., Salvatore, M., Ravnås, R. \& Moscatelli, M., 2015. A comparative study of confined vs. semi-confined turbidite lobes from the Lower Messinian Laga Basin (Central Apennines, Italy): Implications for assessment of reservoir architecture. Marine and Petroleum Geology, 63: 142-165.

Marr, J. G., Harff, P. A., Shanmugam, G., Parker, G., 2001. Experiments on subaqueous sandy gravity flows: The role of clay and water content in flow dynamics and depositional structures. Geological Society of America Bulletin, 113: 1377-1386.

McHargue, T., Prycz M. J., Sullivan, M. D., Clark, J. D., Fildani, A., Romans, B. W., Covault, J. A., Levy, M., Posamentier, H. 
W. \& Drinkwater, N. J., 2011. Architecture of turbidite channel systems on the continental slope: Patterns and predictions. Marine Petroleum Geology, 28: 728-743.

Miall, A. D., 1985. Architectural-element analysis: a new method of facies analysis applied to fluvial deposits. Earth-Science Reviews, 22: 261-308.

Miall, A. D., 1989. Architectural elements and bounding surfaces in channelized clastic deposits: notes on comparisons between fluvial and turbidite systems. In: Taira, A. \& Masuda, F. (eds), Sedimentary Facies in the Active Plate Margin. Terra Scientific Publishing Company (TERRAPUB), Tokyo, pp. 3-15.

Mulder, T., 2011. Gravity processes and deposits on continental slope, rise and abyssal plains. In: Hüeneke, H. \& Mulder, T. (eds), Deep-sea Sediments. Developments in Sedimentology, 63: 25-148.

Mulder, T., Migeon, S., Savoye, B. \& Faugères, J. C., 2001. Inversely-graded turbidite sequences in the deep Mediterranean. A record of deposits by flood-generated turbidity currents. Geo-Marine Letters, 21: 86-93.

Mulder, T., Migeon, S., Savoye, B. \& Faugères, J. C., 2002. Inversely-graded turbidite sequences in the deep Mediterranean. A record of deposits by flood-generated turbidity currents. Reply. Geo-Marine Letters, 22: 112-120.

Mulder, T., Syvitski, J. P. M., Migeon, S., Faugères, J. C. \& Savoye, B., 2003. Marine hyperpycnal flows: initiation, behavior and related deposits. A review. Marine and Petroleum Geology, 20: 861-882.

Mutti, E., 1979. Turbidites et cones sous-marins profonds. In: Homewood, P. (ed.), Sedimentation Detrique (Fluviatile, Littorale et Marine). Institut de Geologie, Université de Fribourg, Fribourg, pp. 353-415.

Mutti, E., 1985. Turbidite systems and their relations to depositional sequences. In: Zuffa, G. G. (ed.), Provenance of Arenites. D. Reidel Publishing Company, Dordrecht, pp. 65-93.

Mutti, E. \& Normark, W. R., 1987. Comparing examples of modern and ancient turbidite systems: problems and concepts. In: Leggett, J. K. \& Zuffa, G. G. (eds), Marine Clastic Sedimentology. Graham and Trotman, London, pp. 1-38.

Mutti, E. \& Ricci Lucchi, F., 1972. Turbidites of the Northern Apennines, introduction to facies analysis (English translation by T. H., Nilsen, 1978). International Geology Review, 20: $125-166$.

Mutti, E. \& Ricci Lucchi, F., 1975. Turbidite facies and facies association. In: Mutti, E., Parea, G. C., Ricci Lucchi, F., Sagri, M., Zanzucchi, G., Ghibaudo, G. \& Iaccarino, S. (eds), Example of Turbidite Facies Associations from Selected Formations of Northern Apennines. 9th International Sedimentological Congress. International Association of Sedimentologists, Nice, France, pp. 21-36.

Mutti, E. \& Sonnino, M., 1981. Compensation cycles: a diagnostic feature of sandstone lobes. In: Abstracts: 2nd European Regional Meeting, 1981. International Association of Sedimentologists, Bologna, pp. 120-123.

Nescieruk, P., Paul, Z., Ryłko, W., Szymakowska, F., Wójcik, A. \& Żytko. K., 1995. Mapa geologiczna Polski, 1:200 000, arkusz Jasto. Polska Agencja Ekologiczna, Warszawa. [In Polish.]

Nichols, G., 2009. Sedimentology and Stratigraphy. 2nd ed., Wiley-Blackwell, 419 pp.
Normark, W. R., 1970. Growth patterns of deep sea fans. American Association of Petroleum Geologists Bulletin, 54: 2170-2195.

Normark, W. R., 1978. Fan valleys, channels, and depositional lobes on modern submarine fans, characters for recognition of sandy turbidite environments. American Association of Petroleum Geologists Bulletin, 62: 912-931.

Nowak, W., 1963. Preliminary results of study on exotics from the Inoceramian Beds of the Skole Series, of several sites in the Przemyśl and the Bircza, Carpathians. Kwartalnik Geologiczny 7: 421-430. [In Polish, with English summary.]

Pickering, K. T., Stow, D., Watson, M. \& Hiscott, R., 1986. Deepwater facies, processes and models: A review and classification scheme for modern and ancient sediments. Earth-Science Reviews, 23: 75-174.

Pickering, K. T., Hiscott, R. N. \& Hein, F. J., 1989. Deep Marine Environments: Clastic Sedimentation and Tectonics. Unwin Hyman, London, 416 pp.

Pickering, K. T., Hiscott, R. N., Kenyon, N. H., Ricci Lucchi, F. \& Smith, R. D. A., 1995. Atlas of Deep Water Environments: Architectural Style in Turbidite Systems. Chapman and Hall, London, 334 pp.

Picot, M., Droz, L., Marsset, T., Dennielou, B. \& Bez, M., 2016. Controls on turbidite sedimentation: Insights from a quantitative approach of submarine channel and lobe architecture (Late Quaternary Congo Fan). Marine and Petroleum Geology, 72: 423-446.

Porębski, S. J. \& Warchoł, M., 2006. Hyperpycnal flows and deltaic clinoforms - implications for sedimentological interpretations of Late Middle Miocene fill in the Carpathian Foredeep Basin. Przegląd Geologiczny, 54: 421-429. [In Polish, with English summary.]

Posamentier, H. W. \& Kolla, V., 2003. Seismic geomorphology and stratigraphy of depositional elements in deep-water settings. Journal of Sedimentary Research, 73: 367-388.

Postma, G., Nemec, W. \& Kleinspehn, K. L., 1988. Large floating clasts in turbidites: a mechanism for their emplacement. Sedimentary Geology, 58: 47-61.

Prélat, A., Hodgson, D. M. \& Flint, S. S., 2009. Evolution, architecture and hierarchy of distributary deep-water deposits: a high-resolution outcrop investigation from the Permian Karoo Basin, South Africa. Sedimentology, 56: 2132-2154.

Rajchel, J., 1989. The geological structure of the San Valley in the Dynów-Dubiecko region. Biuletyn Państwowego Instytutu Geologii, 361: 11-53. [In Polish, with English summary.]

Rajchel, J., 1990. Lithostratigraphy of the Upper Palaeocene and Eocene sediments from the Skole Unit. Zeszyty Naukowe AGH 1369, Geologia, 48: 1-112. [In Polish, with English summary.]

Rajchel, J. \& Uchman, A., 1998. Ichnological record of palaeoenvironment in the transgressive Miocene deposits of the Skole Unit in the Dubiecko region (SE Poland). Przeglad Geologiczny, 46: 523-529. [In Polish, with English summary.]

Rea, D. K. \& Lyle, M. W., 2005. Paleogene calcite compensation depth in the eastern subtropical Pacific: answers and questions. Paleoceanography, 20: PA1012.

Salata, D., 2014. Detrital tourmaline as an indicator of source rock lithology: an example from the Ropianka and Menilite formations (Skole Nappe, Polish Flysch Carpathians). Geological Quarterly, 58: 19-30. 
Salata, D. \& Uchman, A., 2013. Conventional and high-resolution heavy mineral analyses applied to flysch deposits: comparative provenance studies of the Ropianka (Upper Cretaceous-Paleocene) and Menilite (Oligocene) formations (Skole Nappe, Polish Carpathians). Geological Quarterly, 57: 649-664.

Shanmugam, G., 2016. Submarine fans: A critical retrospective (1950-2015). Journal of Palaeogeography, 5: 2-76.

Shanmugam, G. \& Moiola, R. J., 1988. Submarine fans: characteristic, models, classification and reservoir potential. EarthScience Reviews, 24: 383-428.

Shanmugam, G. \& Moiola, R. J., 1991. Types of submarine fan lobes: models and implications. American Association of Petroleum Geologists Bulletin, 75: 156-179.

Skulich, J., 1986. Badania magmowych skał egzotycznych we wschodnich Karpatach Fliszowych na obszarze Polski. Kwartalnik Geologiczny, 30: 135-136. [In Polish.]

Snedden, J. W. \& Liu, C., 2010. A compilation of Phanerozoic sea-level change, costal onlaps and recommended sequence designations. American Association of Petroleum Geologists Search and Discovery, Article 40594, 3 pp.

Stow, D. A. V. \& Shanmugam, G., 1980. Sequences of fine grained turbidites - comparison of recent deep-sea and ancient flysch sequences. Sedimentary Geology, 25: 23-42.

Stow, D. A. V. \& Mayall, M., 2000. Deep-water sedimentary systems: new models for the 21 st century. Marine and Petroleum Geology, 17: 125-135.

Strzeboński, P., 2015. Late Cretaceous-Early Paleogene sandy-to-gravelly debris flowsand their sediments in the Silesian Basin of the Alpine Tethys (Western Outer Carpathians, Istebna Formation). Geological Quarterly, 59: 195-214.

Sumner, E. J., Amy, L. \& Talling, P. J., 2008. Deposit structure and processes of sand deposition from a decelerating sediment suspension. Journal of Sedimentary Research, 78: 529-547.

Ślączka, A. \& Kaminski, M. A., 1998. A guidebook to excursions in the Polish Flysch Carpathians. Grzybowski Foundation Special Publication, 6: 11-71.
Ślączka, A. \& Thompson, S., III, 1981. A revision of the fluxoturbidite concept based on type examples in the Polish Carpathian Flysch. Annales Societatis Geologorum Poloniae, 51: 3-44.

Talling, P. J., Masson, D. G., Sumner, E. J. \& Malgesini, G., 2012. Subaqueous sediment density flows: Depositional processes and deposit types. Sedimentology, 59: 1937-2003.

Uchman, A. \& Wetzel, A., 2012. Deep-sea fans. In: Knaust, D. \& Bromley, R. G. (eds), Trace Fossils as Indicators of Sedimentary Environments. Developments in Sedimentology, 64: 643-671.

Unrug, R., 1963. Istebna Beds - a fluxoturbiditic formation in the Carpathian Flysch. Rocznik Polskiego Towarzystwa Geologicznego, 33: 49-92.

Vrolijk, P. J. \& Southard, J. B., 1997. Experiments on rapid deposition of sand from high-velocity flows. Geoscience Canada, 24: $45-54$.

Walker, R. G., 1978. Deep-water sandstone facies and ancient submarine fans - models for exploration and for stratigraphic traps. American Association of Petroleum Geologists Bulletin, 62: 932-966.

Walker, R. G., 1984. General introduction: facies, facies sequences and facies models. In: Walker, R. G. (ed.), Facies Models, $2^{\text {nd }}$ ed. Geoscience Canada Reprint Series, 1: 1-9.

Warchoł, M., 2007. Depositional architecture of the Magura Beds from the Siary zone, south of Gorlice (Magura Nappe, Polish Outer Carpathians). Przeglad Geologiczny, 55: 601-610. [In Polish, with English summary.]

Wdowiarz, J., 1939. Structure géologique des Karpates dans la région de Dynów. Biuletyn Państwego Instytutu Geologicznego, 10: 1-22. [In Polish, with French summary.]

Woiński, J., 1994. Mapa geologiczna Polski, 1:200 000, arkusz Rzeszów. Polska Agencja Ekologiczna, Warszawa. [In Polish.]

Zavala, C., Arcuri, M. \& Blanco Valiente, L., 2012. The importance of plant remains as diagnostic criteria for the recognition of ancient hyperpycnites. Revue de Paléobiologie (Genève), 11: 457-469. 